\title{
مقدمة مقدم
}

بسبب تزايد التبادلات التجارية في الميدان الدولي بين الثركات و الامم، اصبح التحكيم حاجة ملحة ينظر له باعتباره قضاء اصبلا للمناز عات الناثـئة عنها. وقد ادركت الدولة العر اقيـة الدور المتعاظم للتحكيم، وخصوصـا بعد التحولات التي شهدها البلد، واهمها انتقاله من السوق الموجها الى السوق الحرة، ومـا صـاحب ذلك من جلب للاستتمار ات الاجنيـة لغرض تحقيق التنمية الاقتصـادية. فكانت تلك الظروف بمثابـة المبرر الرئيسـي للجـوء الـى التحكيم وتطوير احكامسه في مشـروع قـانون يتبنـى المبـادئ السـائدة في مجـال حســ المنازعات ، ذات الطابع الدولي على وجه الخصوص ــ ـ ورغم تأتز مشروع قانون التحكيم التجاري العر اقي لعـام | 1 ـ ب بالاتجاهـات السـائدة بمسـائل التحكيم ، الا انـه لا زال حريـاً بالدر اســة و التقويم ، للاسـتفادة مـن الملاحظـات التي ثبتهـا العـاملون و المهتمـون بـالتحكيم على قـانون الاونسـيتر ال النمـوذجي للتحكيم التجـاري الدولي المعدل لعام 7 . . ب، ومنها تحديد القانون الو اجب النطبيق على موضوع النزاع المحكم فيه.

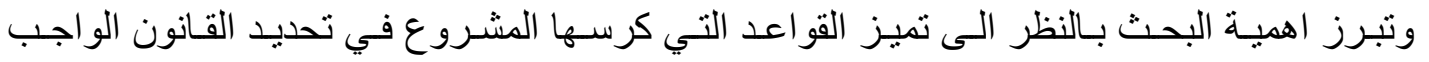
التطبيق على النزاع المحكم فيه، عن القواعد التي تحكم تنـازع القوانين في مجـال العقود ، سو اء من حيث ار ادة الاطر اف في الاختيـار او من حيث سلطة المحكم في تحديد قانون النزاع. فمـا هو القانون الواجب التطبيق على موضوع النزاع المحكم فيه؟ ومـا هو دور ارادة الاطر اف في تحديد القانون الواجب التطبيق على النزاع في التحكيم التجاري الدولي؟ وهل يلتزم المحكم بمـا يلتزم بـه القاضـي من قو اعد ومبادئ لتحديد القانون الذي يحسم النزاع ؟ ومـا هو الاثر الذي يترتب على مخالفة المحكم لمـا تقرره ار ادة الاطر اف في الاختبار؟ ـ كل ما تقدم من الاسئلة سنحاول الاجابـة عنها على وفق المنهج التحليلي في مبحثين ، نتناول في المبحث الاول تكريس حرية الاطر اف في اختيار قانون النزاع ، وفي المبحث الثاني تكريس سلطة المحكم في

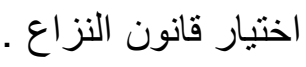

\section{المبمث الاول- تكريس حرية الأطراف في اختيار قانون النزاع}

يختلف التحكيم عن القضاء بأصله الاتفاقي، وانطلاقا من هذا الاصل بتـاح لأطر اف التحكيم اختيار القو اعد التي تحكم موضوع النزاع. فتكاد لا تخلو لائحسة من لوائح التحكيم او معاهدة دولية او قانون وطني متعلق بالتحكيم من نص على تطبيق القانون الذي يتفق عليه الاطر اف في شـان موضوع النزاع الذي يحل بـالتحكيم، ولم يعد هذا الحل مستتندا الى مطلق ارادة المتعاقدين بـل صـار يمثنل احد مبـادئ القانون الدولي

الخاص التي تجيز للأطر اف اختيار القواعد التي يرونها مناسبه لحكم علاقاتهم التعاقدية"('). و انسجاما مـع هذا التوجه، فقد حرصت اللجنة التي وضعت مشروع قانون التحكيم التجاري العر اقي لعام Iل ـ ب(؟) على تكريس هذا المبدأ، حيث نصت المادة ( • ) منه على:( تفصل هيئة التحكيم في النزاع المعروض عليها وفقا لما يلي 


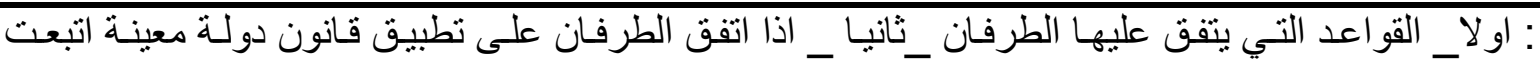
القواعد الموضوعية فيه دون القواعد الخاصة بقواعد تنازع القوانين، مالم يتفق على غير ذلك). وبناء على ما تقدم، سنتعرض في هذا المبحث الى القو اعد التي يختار هـا الاطر اف في مطلب اول و لاختيار هم قانون دولة معينة ليحكم النزاع في مطلب ثان .

\section{المطلب 11لاول - تطبيجز المحكم للقواعد القانونية التي افتنارها الاطراف}

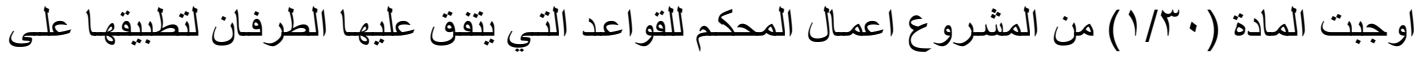
موضوع النز اع بهذف حسمه. الا ان نص المادة المذكورة رغم وضوحه في ايلاء الاولوية والاهمية لاختيار الاطر اف للقو اعد التي تحسم النزاع ، كـان نصـاً يشـوبه الغموض مـن ناحيـة تحديد المقصـود بالقو اعد التـي يختار ها الاطر اف فما هي القو اعد التي ينصب عليها اختيار الاطر اف لحسم نزاعهم امام المحكم؟؟ في معرض الاجابـة عن التسـاؤل الماثل يمكن مواجهة فرضين ، الاول منهما يتمثل باحتمـال اتجاه

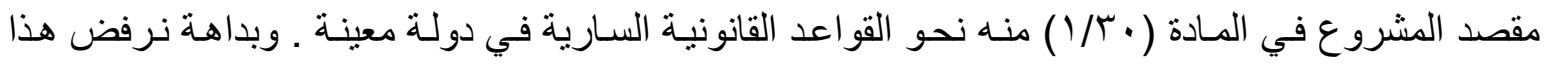
التفسير ، لكون الفقرة الثانيـة مـن نفس المـادة اوجبت على المحكم تطبيق القـانون التـابع لدولـة معينـة على موضوع النزاع عندما تتجهـ ار ادة الاطر اف الى اختياره ، مقيدا نفسـه بالقو اعد الموضوعية فيهه ، وهو امر يجعل من وجود الفقرة الاولى عبثناً على فرض تفسير ها السـابق. امـا الفرض الثاني فهو يتمثل باتجاه نيـة و اضعي المشروع الى اتاحسة المجال لأطر اف التحكيم باختيار قو اعد لا تنتمـي الى دولـة معينـة وانما قواعد موضو عية عبر دولية تكون متعددة المصـادر. وهذا التفسير هو الاكثر قبولا عند الباحث. فـالتطور الذي اتسمت به العلاقات الدولية وما لازم ذلك من الحاجة الى وجود حلول موضوعية تلائم المعطيات الجديدة لهذا التطور وتعمل على تلافي الاختلاف الناجم عن تباين التشريعات الداخلية ، ظهر اتجاه حديث سعى الى خلق بعض الاحكـام الموضـوعية لتحكم الـرو ابط التعاقديـة الدوليـة مباثـرة بمـا يتمشـى مـع طبيعـة هـذه الـروابط

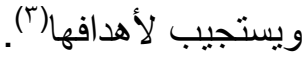

هذه الاحكام الموضو عية كونت ما يعرف اليوم بقانون التجارة الدولية ، وكان هذا الاخير نتاج وجود مجتمع متماسك تقوم بين اعضـاءه علاقات ومبادلات لها خصوصيتها وتتظيمها الذاتي (؛). ذلك للنأي بعقود التجارة عن الاختلافات التشريعية القائمة بين دولة واخرى. وقد جاء في تقرير الامين العام للأمم المتحدة عام ه7 197 تعريفا اجماليا لهذا القانون، حيث عرفه بانـه: (مجموعـة القواعد التي تسري على العلاقات التجاريـة

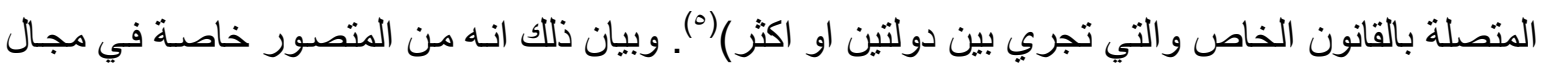

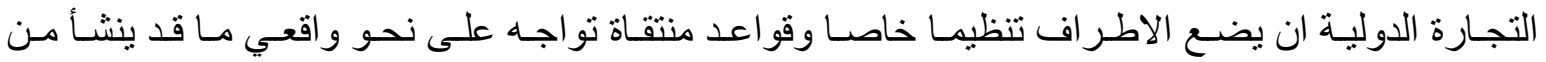
مناز عات، هم الاقرر على تصور ها وعلى وضع ما يلائمها من حلول مبتكرة، ومن امثلة ذلك لجوء اطر اف التحكيم الى المزج بين عدة مصادر فينشئون قانون عقدهم من مجموعة من القو اعد المستخلصـة من تشريعات وطنية او اجنبية(†)، او اتفاقيات دولية او اعراف و عادات التجارة الدولية.

ان مصادر هذه القو اعد ليس معدوماً في الواقع ، فهي تتقرر امـا بالنصوص التشريعية ذات الطابع

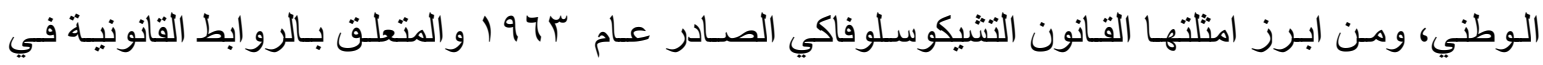
العلاقات التجارية الدولية(') ، او في الاتفاقيات الدولية كاتفاقية فينا الخاصـة بـالبيع الدولي للبضـائع لعام • 191. 
كذلك ما تتضمنه العديد من التشريعات الحديثة في الدول النامية من قو اعد قانونيـة متعلقة بمعاملـة الاستثمار ات الأجنيـة . كذلك فـان قضـاء التجـارة الدوليـة منــنالا بـالتحكيم واوسـاطها المهنيـة كـان لـه دور كبير في خلق القو اعد الموضـوعية للتجـارة الدولية. ففي مجال التحكيم يجد المحكم نفسـه في كثير من الاحيان و لأسباب مختلفة مضطر الى حل النزاع على ضوء قو اعد من خلق عادات واعر اف التجارة الدولية ، قو اعد تستقل بكيانها ومنابعها عن القو انين الوطنية ، ويترتب على ذلك ان يكون البنيان القانوني لقرار التحكيم منبت الصلة باي من القو انين الوطنية اي يكون طليقا الا من عادات و اعر اف التجارة الدولية(^).

اما بالنسبة للممارسة المهنية فقد اوجدت تجمعات مهنية تضم اعداداً من المتعاملين في تجارة معينـة عقوداً نموذجية ضخمة قائمة على تخصص نوعي معين من البضـائع و المنتجات(9) ، مثل عقد نقل التكنلوجيا و المساعدة الفنية وبناء المساكن الجاهزة على التسليم او على الانتاج و المشرو عات ذات النشـاط الاشعاعي وقد زامن ظهور هذا النوع من العقود اهتمام بالغ في البحث عن الظروف التشريعية والقضـائية الملائمسة لها، لان التشريعات الوطنية لم يعد باستطاعتها مواجهة هذه العقود ، فقو اعدها وضعت لنتظيم عقود تقليدية · (). وقد ذهبت محكمة استئناف باريس الى ان عادات التجارة التي استقرت في مجال بيع وشر اء البصل، هي قو اعد قانونية تطبق، حتى ولو لم يتفق الاطر اف على ذلك صر احة ، و لا يمكن قبول الاعتذار بجهلها واذا كان من الممكن الاستناد الى الار ادة الضمنية للأطر اف في تطبيق تلك العـادات ـالقواعد القانونيةــ فأسـاس لـاس

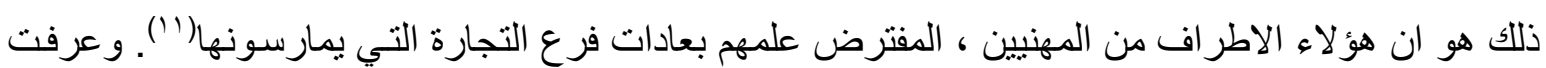
قو اعد القانون التجاري الدولي تعريفات عديدة منها انـه: ( ذلك القانون الذي يوضع مباشـرة ومستقلاً عن كل

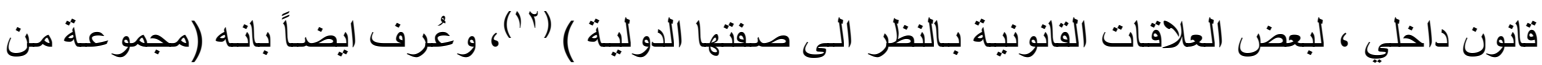
القو اعد و المبادئ و العادات المستمدة من الاوساط التجارية الدولية، والتي تتجدد بصفة مستمرة لحكم العلاقات

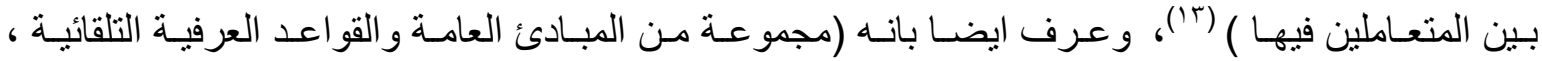

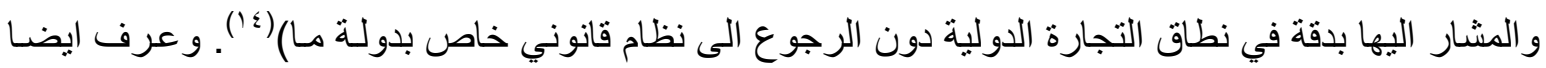
بانه ( قو اعد فردية مستقلة بذاتها في بنيان قانوني من خلق مجتمعات التجارة الدولية)(10). ومن مطالعـة مـا تقدم، يتبين ان مـا يسمى بقانون التجارة الدوليـة يتكون مـن اعر اف وعـادات درج عليها المجتمع الدولي للتجارة و الاعمال و التي نتكل بمجمو عها قو اعد تهتم بتنظيم الروابط العقديـة في مجال المعاملات الدولية.

وقد ثار جدل في اوسـاط الفقه حول قانونية هذه القواعد، فهي تبدو من حيث الظـاهر سواء بسبب اصل وجودها او كيفية تطبيقها مجرد عادات او تطبيقات تتم تلقائيا في اوسـاط المهنة، وهي بهذه المثابـة لا تستأهل النظر على انها قو اعد قانونيـة مجردة(7')، وهي لا تعدو ان تكون مجرد عادات اتفاقية ذات اصل تعاقدي و لا تلزم المتعاقدين بهذه المثابة الا بوصفها شروطا تعاقدية تضمنها العقد وهو مـا ينفي عنها صفة

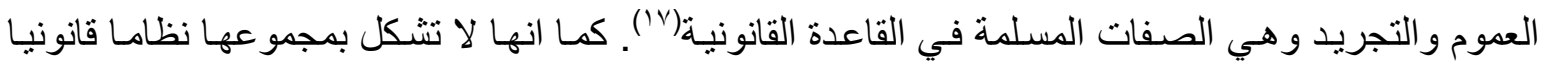
مستقلا بالنظر لافتقادها الجزاء القانوني المستقل عن كل تدخل من جانب الدولة (م'). فضـلا عن ذلك، ان هذه القو اعد التي تثكلت من مجموع اعر اف و عادات التجـارة الدولية ليست نتاجـا لمجتمع يتسم بالقدر اللازم من الوحدة والتناسق ، لأنها تتسم بالغالب بطابع فني متخصص اكثر من اتسـامها بالطابع القانوني فتختلف بهذا 


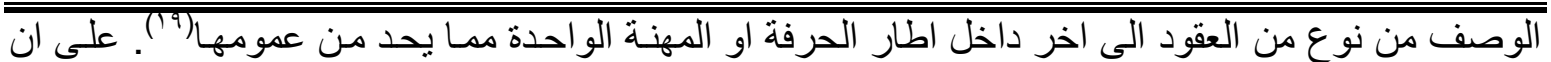
الاتجاه المتقدم لم يلق رواجا، لان احكام قو اعد قانون التجارة الدولية لم تعد مجرد عـادات اتفاقية و انمـا تحولت مع مرور الوقت الى اعراف ملزمة في كثير من المجالات ، و اسـاس ذلك يكمن في ان تقنين العادات السائدة في الاوساط التجارية والمهنية في الثروط العامة للعقود النموذجية قد ادى الى تكرار اتباعها واستقرار العمل بمقتضاها ، فأصبحت بهذا الوصف ذات مضمون عام ومجرد في الوقت الذي شعر فيه المتعاملون في هذه الاوساط بأهميتها وضرورتها لتنظيم مجتمع التجارة الدولي (r.)

امـا من ناحيـة اكتسـائها بصفات القاعدة القانونية، فيرد بعض الشـر اح على ذلك بـان قو اعد التجارة الدولية هي قو اعد قانونية بالمعنى المتعارف عليه ويجب ان تلقى المعاملـة ذاتها التي تلقاهـا القو اعد المذكورة و النظر اليها كنظام قانوني مستقل وقائم في ذاته، وذلك تأسيسا على ان وجود هذه القو اعد مـا هو الا نتيجة

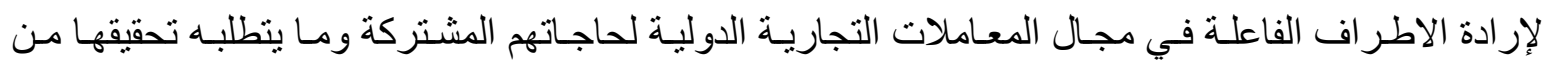

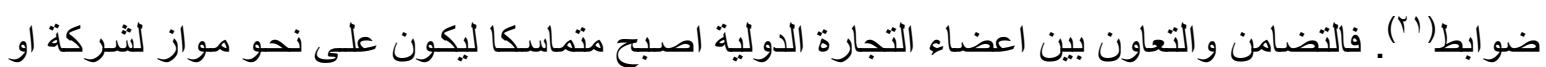
جمعية في دور التكوين، وهو امر يمكن التصور معده امكانية انشـاء تلك الجماعة لقانونها الخاص وتطويره هذا من جانب ، ومن جانب اخر ثبت في الواقع وجود اجهزة تسهر في العمل على احترام القو اعد السلوكية فيمـا يتعلـق بالقـانون الموضـوعي للتجـارة الدوليـة متمثلـة بهيئـات التحكيم التي تسـاعد على تقويـة واستقلال المجتمع الدولي للتجار ورجال الاعمال(rr).

اما من حيث الجز اء، فقد رد البعض(rr) على ذلك بـان الجزاء هو امر خـارج عن القاعدة القانونية وليس ركنا فيها، فهنالك قواعد قانونية معترف بها لم ينكر احد طبيعتها رغم عدم تمتعها بـالجز اء الذي يكفل احتر امها مثنل قو اعد القـانون الدستوري ، فـالجزاء عنصـر اضـافي لفعاليـة القاعدة القانونيـة وليس عنصـر اليسا لوجودها ـ هذا فضـال عن وجود جز اء ذاتي في نطاق قانون التجارة الدولية يمتاز بالاستقلالية التي تضمن احتر ام قواعده، وتلك الجز اءات الذاتية متنو عة منها جز اءات نقدية تتمثل بالمبالغ التي يدفعها الطرف المخالف للالتزز ام التعاقدي ، وجز اءات معنويـة كنشـر واذاعـة عدم تنفيذ حكم التحكيم و اسقاط العضـوية مـن المنظمـة

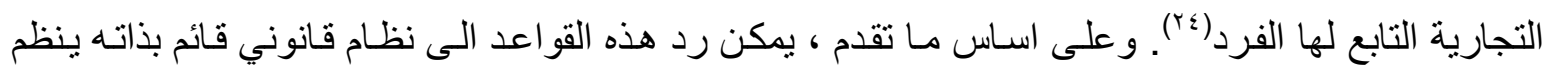
مصالح مشتركة منر ابطة ، رغم انه نظام غير وطني مستقل عن الانظمة القانونية الوطنية. وبهذه المثابـة فـان المحكم عند تطبيقه لقواعد قانون التجارة الدولية على موضوع النزاع ، فانه لا يمارس تحكيما وديا او يقوم بمهمة الوسيط او الموفق بين الاطر اف المتناز عة ، بل يكون تحكيمـا على مقتضى لهـ

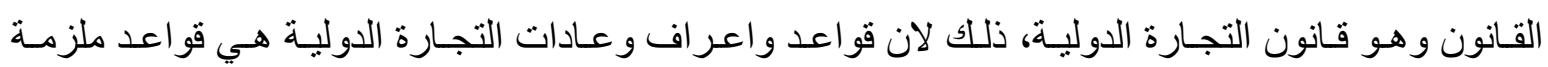

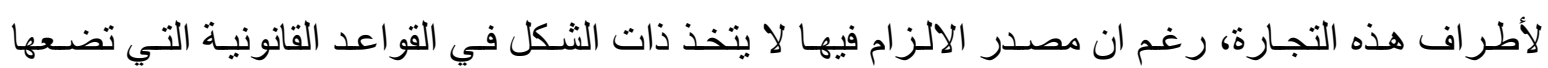

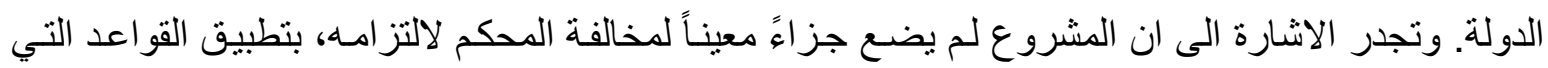

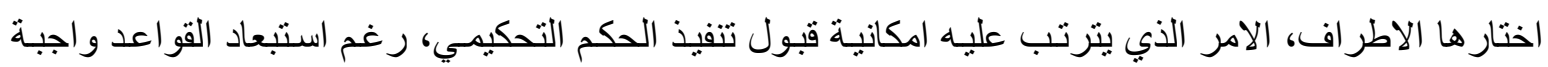
التطبيق، وهو امر يشكل خروجاً عن المبادئ الحاكمة للعلاقات الدولية الخاصة في مجال مناز عات العقود. 


\section{المطلب النانيي - تطبيز المهكم اققانوز دولة معينة افتناره الاطراف}

نصت المادة ( • (T/T) من المشروع على انه :(اذا اتفق الطرفان على تطبيق قانون دولة معينـة اتبعت القو اعد الموضوعية فيه دون القو اعد الخاصة بقو اعد تنازع القو انين ، مـالم يتفق على غير ذللك). من مطالعة النص المتقدم يتضح ان المشروع يتبنى مبدا سلطان الار ادة فيما يتعلق بالقو اعد الحاكمـة للنزاع ، هذا المبدأ الذي يحمل بين جو انبه حرية الاطر اف في الاختيار المشترك بينهم للقانون المطبق على عقدهم(ro)، ويسمى بهى (بقانون الار ادة) ويعرف بانه "القانون الذي يختاره الطرفان ليحكم علاقتهما العقديـة وليكون مصدر اللقو اعد التي تحكمها ولو كان قانون اخر هو الواجب التطبيق عند عدم اختيار الطرفين لذلك القانون(بآـو ويترتب على الايضاح المتقدم التزام المحكم وتقييده بهذا القانون بكل قو اعده وفقا لمصسادرهوبالترتيب او التسلسل المقرر فيـه(YV). ويتم اختيـار هذا القانون عن طريق احد نصـوص العقد محل النزاع او بمقتضى مشـارطة تحكيم مستقلة(^^ا)، و لا يشترط ان يكون هذا القانون وطنيا كمـا يجوز ان يكون اجنبيا اي ان يكون مغاير اللقانون واجب التطبيق على النزاع في حالة عدم اختيار الاطر اف لأي قانون، كما يكون لهم اختبار قانون الدولة التي يجري فيها التحكيم(ج9)

وهذا الامر تقره الانظمة القانونية في مجال التحكيم على الصعيدين الداخلي و الدولي (•)"، وهو يمثل مبدا مخالفـا للمبدأ السـائد في الفروض التي يطرح فيها النزاع على القاضي الوطني ـ فالمحكم يكون اكثر تحررا من القاضـي في هذا المجـال ، ويجد هذا التحرر اساسـه في قاعدة مادية من قو اعد القانون الدولي الخاص لاى قضاء التحكيم تخول لأطر اف الر ابطة العقدية حق تنظيمها وفقا لما يجدونه مناسباً من اثتر اطات تعاقدية ، بما في ذلك حقهم في اختيار قانون دولة معينة تتولى احكامـه تنظيم العلاقة بين المتعاقدين ، فالمحكم رغم ادر اكه لوظيفته القضائية الا انه يشعر بحقيقة انه يستمد اختصاصده القضائي من ار ادة الخصوم، فان كان موقع القاضي يسمو على العقد الدولي محل النزاع و اطر افه مما يسمح له اخضـاعه لقو اعد تتـازع القو انين فـان المحكم على العكس يجد مكانه في نظام من صنع الاطر اف ويستمد اختصاصه من ار ادتهم(")". وترتيبا على ما تقدم، فان المحكم لا يكون ملزما بتوطين العقد عندما يختار اطر اف النزاع قانونـا مـا لينطبق على العقد على العكس من القاضي تماما ـ فالقاضي ملزم بـان يطبق القانون الذي اختاره الاطر اف ، وان كان اطر اف النزاع في العقد الدولي ، قد اختاروا قانونـاً اجنبياً لينطبق عليه، بشرط ان يكون متصـلا بالنزاع بوجود رابطة جدية ما بين العقد وبين القانون المختار (r؟r).

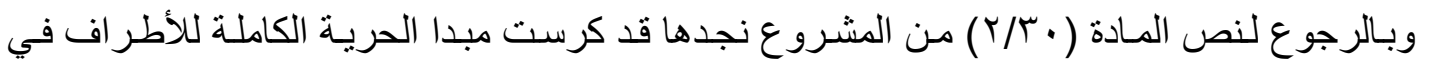
اختيار اي قانون يرونه مناسبا لحكم علاقتهم العقديـة ، فالمشروع لم يشترط لإعمـال مقتضى حريـة الاطر اف

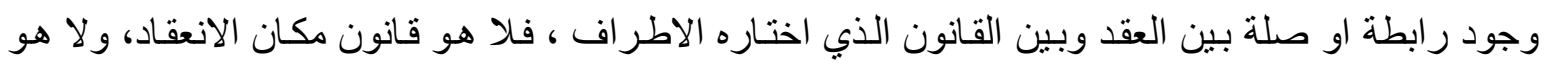
قانون التنفيذ ، ولا اي قانون اخر على صلة بالنزاع، ذلك ان الاطر اف عندما تختار قانونـا لبلد مـا لا علاقة لهـ

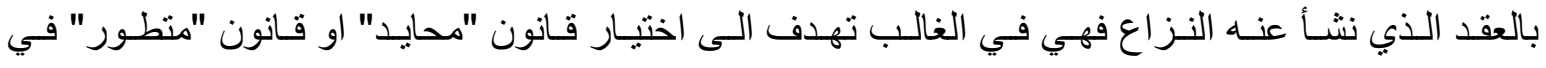

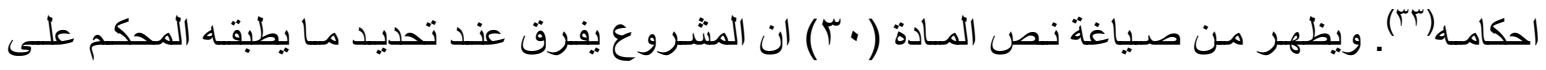
موضوع النزاع بين (القو اعد التي يتفق عليها الطرفان ) من جهة، وبين اتفاقهما على (تطبيق قانون دولنة معينة من جهة اخرى ) اذ ان المقصود بالأخيرة هي القواعد الموضوعية السـارية في دولة مـاو التي يختارهـا موليا 
الاطر اف لتنطبق على النز اع بتفضيلها على غير هـا من القو اعد الوطنية المماتلـة في مختلف الدول ، وذللك لميزة تمتاز بها، سواء من حيث حياديتها، او من حيث تطور هـا بمحاكاة نوع من العلاقات القانونية غير المعروفة في كل الانظمة القانونية.

اكثر من ذلك، يتضح من مطالعة نص الفقرة الثانية من المادة ذاتها من المشروع انهه لم بقيد ان تكون القو اعد التي يطبقها المحكم و التي تمثل القانون المختار منتمية جميعها لقانون واحد، فبإمكان الاطر اف الاتفاق على ان يفصل المحكم في النزاع طبقا لعدة قو اعد مستمدة من اكثر من قانون وطني(๕). فبإمكان الاطر اف

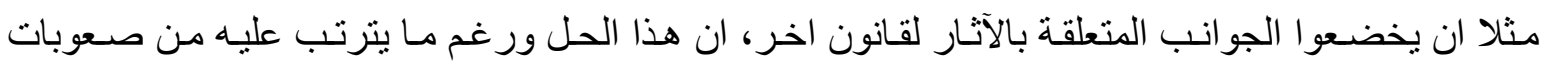

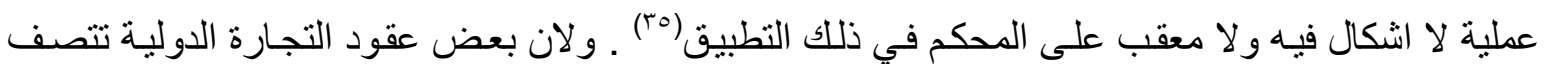
بطول مدد تنفيذها لما لها من طبيعة خاصة ، فقد تتغير احكام قانون الدولة التي يتوجب على المحكم تطبيقها على النزاع بنـاء على اختيار الاطر اف لها، ذلك امـا بإلغائها او بتعديلها، فتنشـأ لدى المحكم صعوبة تحديد القانون الواجب التطبيق على النزاع ، فهل يكون القانون السـائد وقت انعقاد العقد هو المختص بحكم العلاقة محل النزاع؟ ام القانون السائد وقت انعقاد هيئة التحكيم هو المختص بحكم العلاقة محل النزاع؟. وتتوقف الإجابة عن هذا التساؤل، على ما إذا كان الأطر اف قد ضمنوا اتفاقهم شرطا يقضي بتجميد القانون الو اجب التطبيق على علاقتهم، فيمـا يسـى بشـرط الثبـات التشـريعي، أم خـلا اتفـاقهم مـن مثنل هذا الثرط، فلو أن الأطر اف لم يضمنوا اتفاقهم مثنل هذا الثرط، فإن على هيئة التحكيم تطبيق القانون الوطني المختار بالحالة التي هو عليها وقت أن دعيت المحكمة لإصدار هذا التحكيم، أما إذا تضمن الاتفاق هذا الشرط هئه فإن القانون الواجب التطبيق، يكون هو ذلك الموجود وقت انعقاد اتفاق الاستثمار (بr). ولعل مما تجدر الاشارة اليه ان اختيار الاطر اف لقانون النزاع قد يكون صريحا وقد يكون ضمنيا ، و الاختيار الصريح يأتي في صالح كل الاطر اف في خصومة التحكيم ، اذ يسهل مهمة المحكم المخول بالفصل في النزاع ، حيث يكون القانون الذي يحكم جوهر النزاع واضـح امامـه لا يكلفه عنـاء البحث و الخوض في الار ادة الضمنية. بذللك يلتزم المحكم بتطبيق القانون المختـار صـر احة من قبل كل الاطر اف فينسجم تنفيذ المحكم لالتزامه الماتل حينئذ مع صالح اطر اف التحكيم ، حيث يتوقع كل منهم القانون المطبق عليه بنـاء على

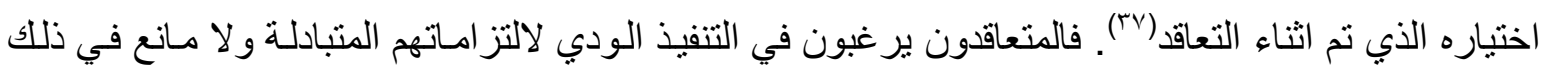
مـن ان يعدوا مسبقا القو اعد القانونيـة التي تسـاعد على حل مـا يمكن ان يثور مستقبلا من مناز عـات حول

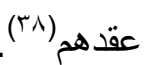

و لا تثار مشكلة اذا كان الاطر اف قد اختاروا قانونا لحكم نزاعهم بشكل صريح، لكن المشكلة الحقيقية التي تواجه المحكم وتقف عقبةً كؤودً في طريق الحل هي عدم اتفاق الاطر اف على الاختيار الصريح لقانون معين ، الا ان ذلك لا يعني انتهاء كل دور لهم حيث تكون لهم ار ادة ضمنية تتجها نيتهم من خلالها ، ويقع عبء اكتشافها على عاتق المحكم وذلك من خـلال القرائن التي تكثف عن الار ادة الضمنية للأطر اف ومن هذه القرائن اللغة المستعملة في العقد او في التحكيم او المكان الذي اتفق على اجر اء التحكيم فيه ، كمـا ان استخدام اصطلاحات مقررة في قانون معين يدل على اتجاه ار ادة المتعاقدين نحو تطبيق هذا القانون على 
العقد في مجموعهه وكذللك يمكن استخلاص الار ادة الضمنية للأطر اف من التجائهم الى مركز تحكيم يعتنق لائحة معينة او بارتباط العقد بعقود اخرى تخضع لقانون معين(ب9).

و التساؤل الذي يبرز في هذا الصدد، مـا هو مصير حكم التحكيم حينما يستبعد المحكم قانون الدولة

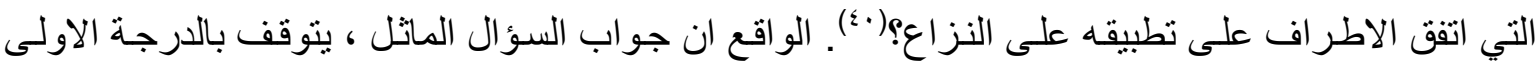
على معرفة ما اذا كان مشروع قانون التحكيم العر اقي يعد استبعاد القانون الواجب التطبيق على النزاع سببا

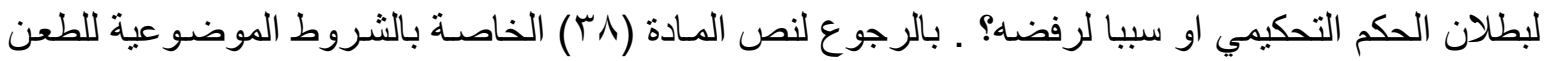
ببطلان الحكم التحكيمي و المـادة ( اء) الخاصـة بالثروط الموضو عية لطلب تتفيذ الحكم التحكيمي ، نجد ان المشروع لم يكرس حكما لفرض مخالفة المحكم للقانون الذي يحكم النزاع ـ وهذا الموقف يأتي على العكس مما هو معمول به في بعض الانظمة القانونية التحكيمية( (\&). ان خلو مشروع قانون التحكيم من جزاء يفرض على المخالفة التي يرتكبها المحكم باستبعاد قانون النزاع ، يمثل مشكلة خطيرة . فلا قيمة لإعطاء الاطر اف حريـة اختيـار القانون الذي يرونـه مناسبا ، وسلطة المحكم تجاهه مطلقة ، حيث لا معقب عليه في ذلك. ويترتب على ما تقدم ، بقاء امكانية تغيير القانون الواجب التطبيق على النزاع متاحة للمحكم ، وتبعا لذلك يتغير الحكم بنتائجه التي توصل اليها المحكم. وقد يقول قائل، دفاعا عن المشروع في موقفه السابق ، بان بالإمكان ابطال حكم التحكيم الذي بنيت نتائجهه على احكام قانون

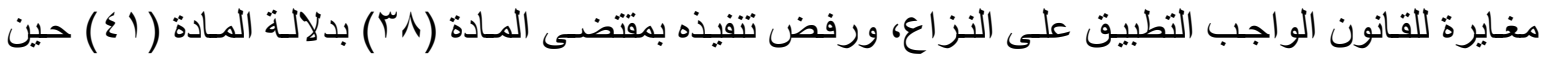
جعل المشروع اسباب البطلان هي ذاتها اسباب رفض التنفيذ- بنـاء على الفقرة الرابعة من المـادة (^ץ) التي جاء فيها :( لا يجوز الطعن في قرار التحكيم امام المحكمة المختصة الا بطلب ابطلال يقدم في احدى الحالات الاتية : رابعا ــ اذا تناول قرار التحكيم مسائل لم يتضمنها اتفاق التحكيم او جاوز حدود هذا الاتفاق) ـ يرى الباحث ان الاحتجاج بهذه الفقرة لطلب ابطال حكم تحكيمي استبعد فيه القانون الواجب التطبيق على النزاع ، هي ليست خاصة بهذا السبب بالتحديد ـ كما انها تفتح الباب لمناقثنة النزاع مرة اخرى امـام المحكمة المختصـة المطلوب منها ابطال الحكم او رفض تنفيذ ، وهي صلاحية لا يتسنى للقاضي المختص ممارستها .

\section{المبمث الثاني- تكريس سلطة المكم في اختيار قانون النزاع}

اذا اتفق الاطر اف على قانون يحسم به النزاع فلا تتور مشكلة في الامر، فالقانون محدد سلفا وكل مـا على المحكم هو تطبيق ذللك القانون الا ان المشكلة الحقيقيـة التي تثار عند غياب ارادة الاطر اف للقـانون الواجب التطبيق على النزاع موضوع التحكيم ، فوفقا لأي قانون يقرر المحكم حسم النزاع ؟ . لم يترك المشروع هذه المشكلة دون حل ، فقد اوكل للمحكم مهمة حسم النزاع باختياره لقانون دولة معينة شريطة اتصاله بالنزاع ، كما سمح للمحكم حسم النزاع بمقتضى قو اعد العدالة والانصـاف. فقد نصـ المادة (•r) من المشروع (ثالثا _ اذا لم يتفق الطرفان على القواعد او القانون الواجب التطبيق طبقت هيئة

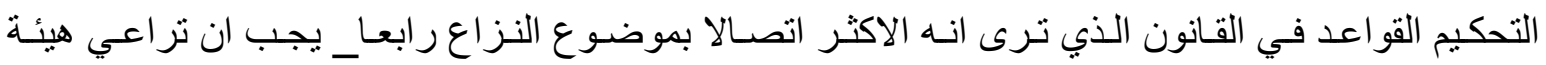
التحكيم عند الفصل في موضوع النزاع شروط العقد محل النزاع و الاعر اف التجاريـة المتبعـة في نوع النشـاط _خامسا _لا يجوز لهيئة التحكيم الفصل في النزاع ، وفقا لقو اعد العدالة والانصـاف الا اذا اتفق الطرفان على 
ذللك كتابـة). و عليـه سنقسم هذا المبحث الى مطلبين ، نتطرق في الاول الى تطبيق المحكم للقانون الاكثر اتصالا بالنزاع، وفي المطلب الثاني نتعرض لحسم النزاع وفقا لقو اعد العدالة والانصاف .

المطلب 1لاول - تطبيزق المحكم للقانوز الاكثر اتصالا بالنزاع

نصت المادة (• ب/؟) من مشروع قانون التحكيم العراقي على: ( اذا لم يتفق الطرفان على القواعد

او القانون الواجب التطبيق طبقت هيئة التحكيم القواعد في القانون الذي ترى انه الاكثر اتصـالا بموضـوع النزاع ) . من مطالعة النص المتقدم ، يتضح ان المشروع ترك للمحكمين حريـة اختيار القواعد القانونية التي تفصل في النزاع ، ولكن هل تكون سلطة المحكم في هذا الاختيار طليقة ام مقيدة ؟ .

تجدر الاشارة قبل الاجابة عن التساؤل السابق اثارته، الى ان الفرض الماثل يلقي على عاتق المحكم

الدولي عبء التصدي لحل هذه المشكلة ليمارس دور ا خطيرا يجعل من التحكيم باسره نظامـا مر هونـا بعملية الاختيار ، اذ من المحتمل ان يتعرض الحكم الذي يصدره المحكم للبطلان ولعدم التنفيذ على السواء ، حين مجانبته تطبيق القانون الانسب بكونـه القانون الاكثر اتصـالا بـالنزاع. وفي مقابل هذه المسؤولية، يتسم هذا المنهج بالمرونة قياسا بالمنهج التقليدي المتمثل بحل تنازع القو انين عبر قو اعد الاسناد ـ وتتجسد هذه المرونـة في المركز القانوني للمحكم باعتباره قاضي خاص ، فلا يوجد قانون اختصساص ( قانون القاضي ) بالنسبة لله ، فاذا كان القاضي الوطني مقيدا باتباع القو اعد القانونية لقانون دولته التي يصدر احكامهـ باسمها ويتعين عليه اتبـاع قو اعد الاسناد التـي يكرسـها هذا القانون التي تقوم بوظيفة ارشـاده الى القانون الواجب التطبيق على

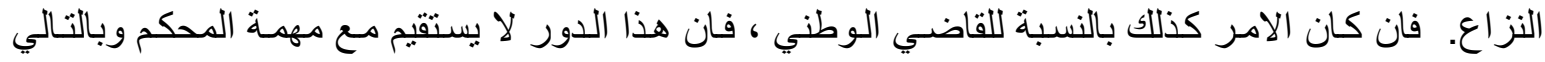

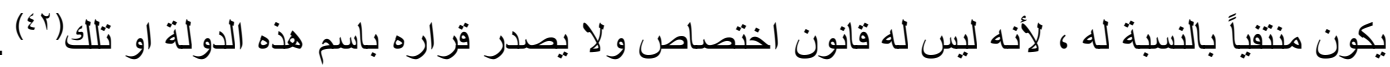
وتأسيساً على ما تقدم، فان المحكم يتمتع بسلطة تقديريـة واسعة في اختيار قانون النزاع ، و اذا كان الامر كذلك ، فـان هذه السلطة والحريـة التي يتمتع بها المحكم هي ليست طليقة ، بل مقيدة باختيار القانون

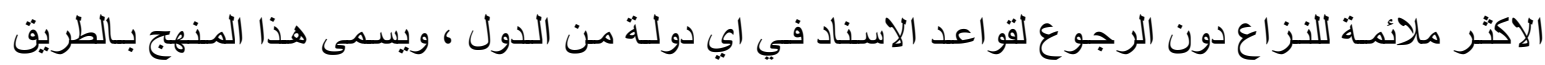
المباشر (ז).

وقد لاحظ جانب من الفقه(؛؛) ان الاعتماد على هذا المنهج ، في تحديد القانون الواجب التطبيق على النزاع بطريقة مباشرة ، من شأنه ان يغيب الاختيار الضمني للقانون الواجب التطبيق على النزاع ـ لذا فمن الافضل للمحكم ان يكون على حذر في تطبيق الار ادة الصريحة ، فان لم توجد ، فعليه التفتيش عن الإر ادة الضمنية ، لان اختيار الاطر اف هو قطب الرحى بالنسبة للقانون الذي يحسم به النزاع. ووفقا لما ذكر من معطيات، ييقى التساؤل مطروحا في هذا الصدد: مـا هو القانون الذي يتعين على

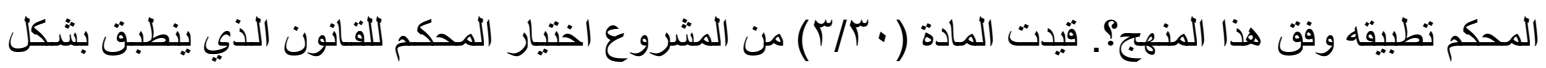
مباثـر على موضـوع النزاع بوجوب ان يكون هذا القانون هو الاكثر اتصـالا بـه دون تحديد ضوابط لهذا الاتصال ، تاركا الامر لمطلق تقدير المحكم لما يراه من قانون انسب او اكثر اتصالا بالنزاع. الواقع ان القانون الاكثر اتصالا بالنزاع يتميز بالنسبية ، لأنـه يختلف بـاختلاف ظروف النزاع التي

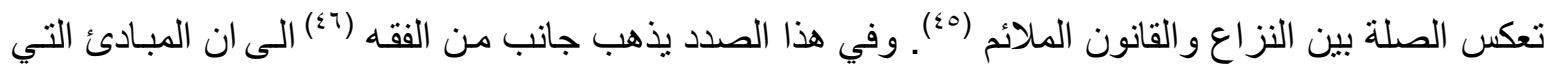
يستتد اليهـا التحكيم في هذا الفرض والتـي من اهمهـا استقلال المحكم الدولي عن جميع الانظمـة القانونيـة 
وحريته في تحديد وتطبيق قانون العقد الدولي ، هذه المبادئ ادت وتؤدي الى نشوء "مخلوق جديد " ينجم عن التطبيق "المجمع" او "الجمعي" لعدد من قواعد القانون الدولي الخـاص للعقود وللأسس التـي يقوم عليهـا التحكيم الدولي ، ويطلق على هذا المخلوق الجديد تسمية "العدالة التحكيمية بدون قو اعد قانونية " ، لان العدالة ـ وفقـا لهذا الاتجـاهـ الناتجـة عن حكم المحكم هـي عدالـة شخصية ، حيث يكون بإمكانـه ان بحسم النزاع المطروح امامه بـون الاستتاد الى قو اعد قانونية معياريـة بـالمعنى الفني الدقيق ، وبذللك يقوم المحكم بمهمة خلق الحل الذي يحسم به النزاع ـ وتتيح له هذه المكنة اختيار القو اعد القانونية التي تحويها الانظمـة القانونيـة المختلفة، وتعد هذه الاخيرة بالنسبة للمحكم بمثابـة "موديلات" او "نماذج" يختار من بينها مـا يتفق مع ميوله ومعتقداته وفكرته الثخصية عن العدل و العدالة .

ورغم التسليم بحرية المحكم في اختيار حسم النزاع وفقا للقانون الذي ير اه على صلة بـه اكثر من القو انين الاخرى المتز احمـة، الا ان الباحث يرى ان الاتجـاه سـالف الذكر لا يمكن قبولـه على اطلاقهـ ، لان المحكم لا يملك حسم النزاع وفقا لمعايير العدالة التي ير اها هو حسب مقتضيات كل نزاع على حدة مـالم يكن مخو لا بالصلح من قبل الاطر اف، وهذا بالتالي يحتم عليه ان بحسم النزاع وفق قو اعد قانونية معينة . وفي اتجاه ثان يذهب بعض الفقه(\&) الى ان المحكم مخير بتطبيق القو اعد التي بر اهـا ملائمسة للنزاع سواء كانت هذه القو اعد هي المبادئ السـائدة في القانون الدولي الخـاص او يعدـد الـى تطبيق قو اعد تنـازع القوانين المنصلة بالنزاع المطروح تطبيقا جمعيا او شاملا، لكنه في جميع الاحوال مقيد باختيار القواعد التي تستجيب بصورة امثل للتوقعات المشروعة للأطر اف، لان هذه الاخيرة هي محور ارتكاز المحكم الدولي لئي ومهمته الاساسية حينما يحسم النزاع ، و على المحكم وهو في سبيل اختيار قو اعد تكرس التوقعات المشروعة للأطر اف ان يضع في الاعتبار اعمال قو اعد البوليس و القو اعد الامرة. ورغم وجاهـة الر أي المتقدم، الا ان الباحث يـرى انـه ليس مـن السـهل على المحكم الوقوف على القانون الذي يحقق التوقعات المشروعة للأطر اف، الذي يؤكد صعوبة هذا الفرض ، ان عدم اختيـار اطراف التحكيم لقانون مـا ـ صـر احةً او ضمناً - منشؤه صعوبة توقع تحقيق مصـالحهم المتناز عـة تحت مظللة اي قانون ، تاركين هذا الامر لقرار المحكم في هذا الخصوص. فاذا كان الوضع كذللك بالنسبة للأطر اف، فكيف بالنسبة للمحكم الذي انيطت به مهمة الفصل بالنزاع و هو طرف خارج عنه؟؟ .

وفي رأي اخر يرى جانب من الفقه ان المحكم قد يجد نفسه مخيرا في تطبيق احد الخيارات الاتية:او لا:- المبادئ القانونية المشتركة :- ووفقا لهذا الاختيـار يطبق المحكم المبادئ القانونيـة المشتركة بين الامم المتمدينة و المتعلقة بعقود التجـارة الدوليـة ، وبهذا التطبيق يخرج المحكم موضـوع النزاع من حكم القوانين

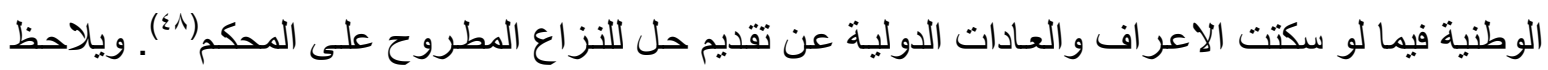

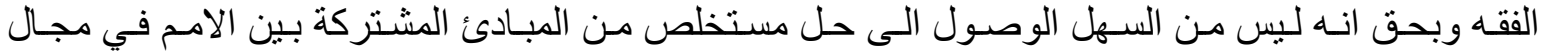
العلاقات التجارية الدولية ، هذا فضلا عن عدم كفايتها لإعطاء حل في مسائل عديدة الامر الذي يحنم الرجوع لقو اعد الاسناد بشأنها مثل الاهلية وعيوب الار ادة وتقادم الالتز ام والمدة التي يجب اعلان البائع فيها بـالعيوب 


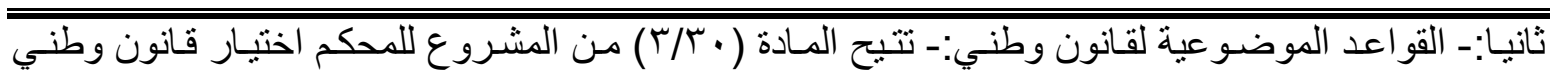
لأحدى الدول لبطبق على النزاع بشرط ان يكون هو القانون الانسب للنزاع وهو لا يكون كذلك مـا لم يكن القانون الاكثر صلة بالنزاع ـ وامام مرونة نص المادة (• ب/ع) من المشروع قد يجد المحكم ان القانون الاكثر اتصالا بالنزاع هو قانون مكان تتفيذ العقد او قانون محل ابرامـه او قانون بلد المصدر او قانون بلد المستورد او قانون بلد جنسية الطرفين او قانون الدولة التي يجري فيها التحكيم او الدولة التي يوجد فيها فرع الثـركة المرتبطة بالعقد المتضمن شرط التحكيم، وهو الحل المكرس تطبيقا(0) وتنظير|(10). وفي اتجاه اخر نرجحهـ،

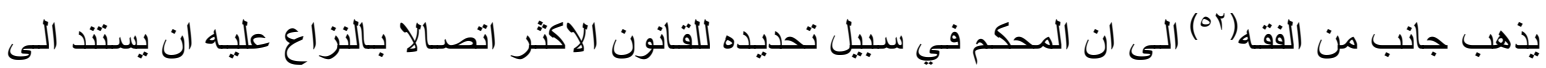
تركيز النزاع تركيز ا موضو عيا بتحديد طبيعته الذاتية، وذلك من خـلال تحديد محل تنفيذ الاداء المميز في

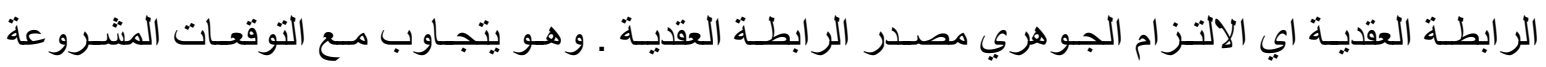

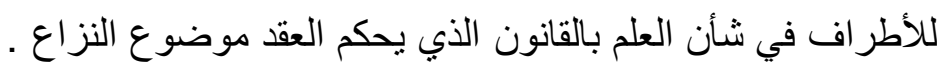
وتطبيقا لذلك، اعتبرت هيئة تحكيم غرفة التجارة الدولية في فرنسـا ان مجرد نوقيع العقد في بـاريس

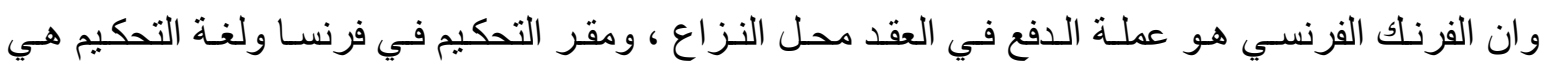

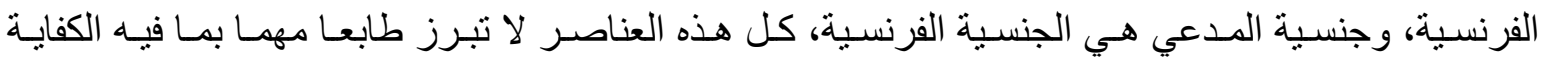
لاستتناج ان الاطر اف اختاروا بشكل ما ولو ضمنا القانون الفرنسي ليحكم عقدهم ، لذاو واعمالا لمعيار القانون

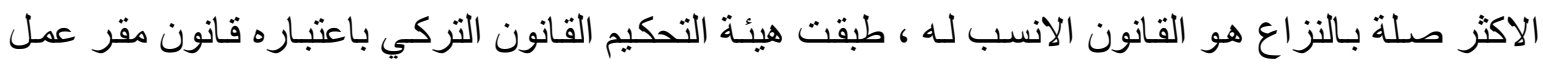
المدعى عليه الذي يقوم بالأداء المميز (or) وتجدر الاشارة الى ان المحكم في تحديده للقانون الانسب للنزاع ، يتقيد بمـا تمليه المـادة (• (ك/乏) من المشـروع. حيث يتوجب ان يراعي في هذا التحديد شـروط العقد التي تواضـع عليها الاطر اف ، و العرف التجاري السائد وقتنئذ. و استتادا لما تقدم ، قضي بأن "يحدد المحكم النزاع وفقا للقو اعد القانونيـة التي اختارهـا الاطر اف، واذا فنشل الاطر اف في القيام بمثل هذا الخيار، يفصل المحكم في النزاع وفقا للقو اعد القانونية التي

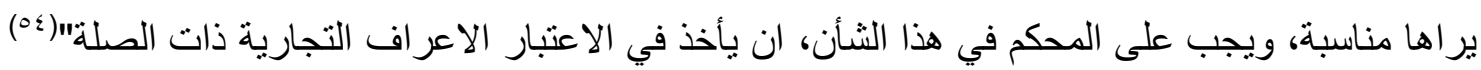
و السؤال الذي يطرح بعدما تقدم بيانه، هل بالإمكان طلب المحكوم عليه بطلان حكم التحكيم او رفض تتفيذه لاستبعاد المحكم القانون الاكثر اتصـالا بـالنزاع؟ ـ لـ يكرس المشروع حكمـا لهذا الفرض، لذا يعتقد الباحث انه لا يمكن الطعن بالبطلان وطلب رفض تتفيذ حكم التحكيم الذي جانب القانون الانسب للنزاع، لان المشروع منحه سلطة تقديرية في هذا الثأن ، ولعدم اعتبار استبعاد هذا القانون سببا مبررا للطعن بـالبطلان ولرفض التنفيذ ـ و التوصل لهذه النتيجـة امـر متوقع، خصوصـا في غيـاب المعيـار الذي يستند اليـه المحكم للوصول الى القانون الاكثر اتصالا بالنزاع في مشروع قانون التحكيم التجاري العراقي .

\section{المطلب الثانيي - تطبيزة المحكم لقواعد العدالة والانصاف}

اتاح نص المادة ( • ب/ه) للمحكم ممارسة سلطته في حسم النز اع وفقا لقو اعد العدالة والانصـاف اذا ما اتفق الطرفان على تخويل المحكم بتلك السلطة، فيكون حسم النزاع وفقا لقو اعد العدالة و الانصـاف بدون ان تكون هناك ضرورة للرجوع الى قواعد قانونية اخرى. لكن ما المقصود بقو اعد العدالة محل التطبيق في هذا 
يعرف البعض قو اعد العدالة في مجال التجارة الدولية بانها : (مجموع الافكار و المفاهيم التي تسود

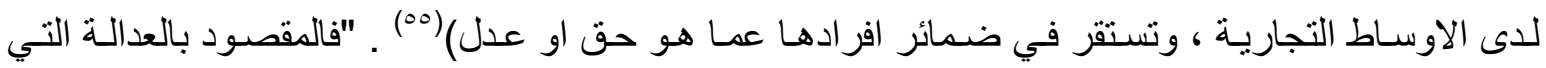
يستلهم منها المحكم الحل الو اجب الاتباع في حالتتا ليس هو العدل المطلق، وانمـا هو مفهوم العدل كما يعرفه مجتمع التجارة والمال ـ فالقاضي او المحكم، اذ يستلهم العدل المطلق ليخلق حلا يو اجه بـه النقص في التشريع او القانون بصفة عامة ، فهو يقوم بما كان يقوم به المشرع فيما لو تبين هذا النقص ـ ابي انه يقدم حلا وضعيا

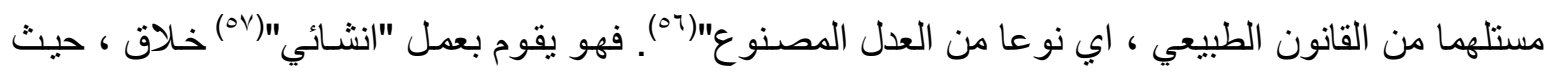
يكون مخو لا السلطة من الطرفين في ان "يثرع" بنفسه حلا فرديا للنز اع قد يطابق الحلول التي يقدمها القانون

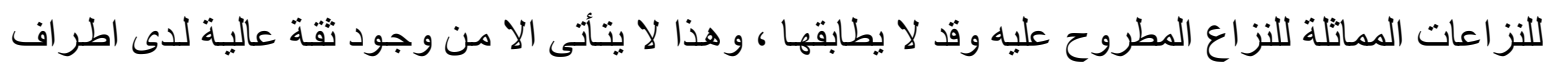

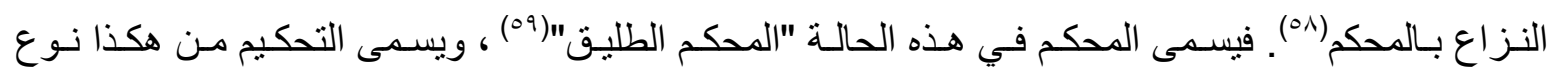

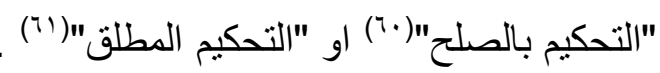

ويؤيد الباحث ما يذهب اليه البعض(rآ) من ان اعطلاء المحكم سلطة الفصل في النزاع وفقا لقو اعد العدالة و الانصاف ، يتضمن صياغة شديدة المرونـة، لان ايلاء المحكم هكذا سلطة من قبل اطر اف التحكيم الذي اختاروه ينم عن ثقة عالية في شخصسه ، ذلك لان مفهوم العدالة مفهوم نسبي ، ويتأثر بالنهايـة بثقافة

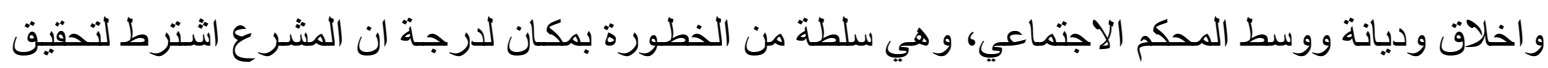

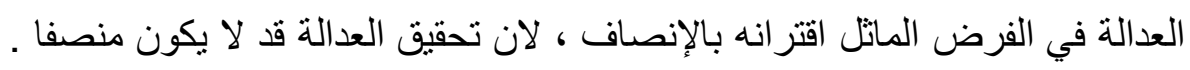
ومطالعـة التطبيقـات القضـائية، تتبـئ عن اعتر اف القضـاء بالحريـة الكاملـة للمحكم في تقدير الحل للحاسم للنزاع وفق مبتنيات الانصاف بالوسائل التي يرتنيها. فقد قضي "وحيث ان التحكيم هو مطلق ، لذلك

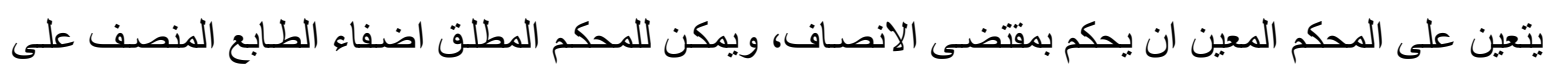
الحل الذي يقرره للنزاع المطروح عليه ، وبالتـالي اعتمـاد المستتدات التي تخدم هذا الحل دون سواها من المستندات المبرزة ، ويقتضي رد ما ادلي به خلاف ذلك ... وليس لمحكمة الاستئناف ان تر اقب كيفية تفسير القانون من قبل المحكم او كيفية تطبيقه للقاعدة القانونيـة او كيفية تفسير المستندات او استخر اج النتائج التي توصل اليها القرار التحكيمي"("آن. يتضح مما تقدم، ان اعطاء المحكم سلطة الفصل في النزاع وفقا لقو اعد العدالة والانصـاف يهدف في الو اقع الى تحرير المحكم من التقبد بأية نصوص تشريعية او قواعد قانونية أبا كان مصدر ها ، ليقوم بنوع من اعن

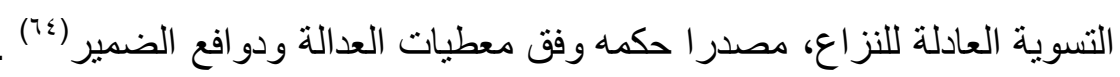
ويعرف هذا النوع من التحكيم بانه "ذلك التحكيم الذي تخول فيه الاطر اف لهيئة التحكيم الفصل في

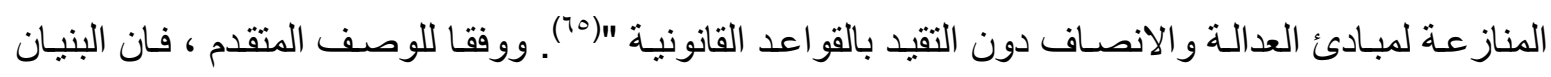
القانوني للقرار الذي يصدره المحكم منبت الصلة بابي من القوانين الوطنية ، ويفترض هذا الامر بـان اطر اف بـاف التحكيم يستطيعون تخطي كل امكانية لربط العقد التجاري الدولي بنظام قانوني معين ومن ثم استبعاد اي

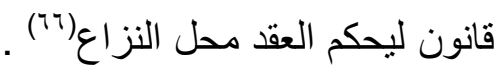




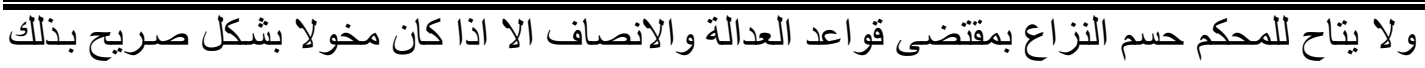

من قبل الاطر اف(Y`). فالإر ادة لا تعقد السلطة للمحكم في هذا النوع من التحكيم ، ما لم يكن معبرا عنها بشكل صريح وواضح(^)، حيث لا يكون دور للإر ادة الضمنية في هذا الصدد.

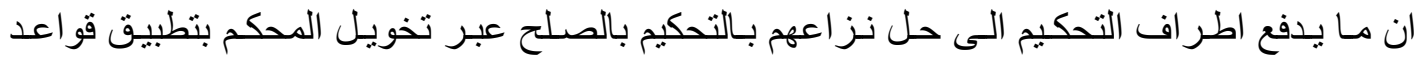
العدالة، هو ان قو اعد القو انين الوطنية قد تضيق او لا تصلح لإعطاء حل عادل للنزاع بسبب تعقد العلاقات

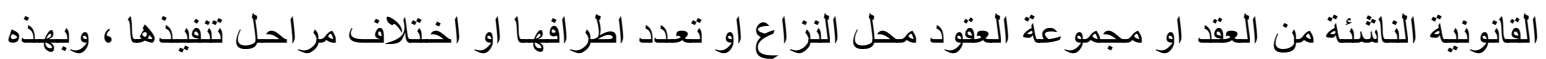
المثابـة فـان العدالة في التحكيم بالصلح ليست وسيلة لتفسير نصوص العقد او القوانين و لا هي وسيلة لحل تنازع القوانين او للحكم في النزاع وانما هي غاية يسعى اليها المحكم الطليق(99). ففي ظل التحكيم بالصلح لا يقصد الطرفان من تخويل الهحكم مهمة التحكيم بالصلح تعطيل تطبيق القانون الوطني الذي كان يحكم النزاع اصلا بزعم عجز هذا القانون عن اعطاء حلول عادلة ، بل يقصدان اتاحـة الفرصـة للمحكم الطليق البحث عن

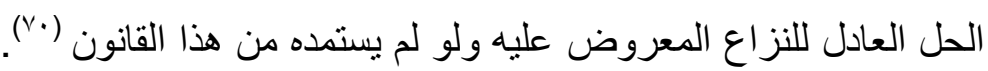
ويتجه جانب من الفقه(Y) الى تأسيس سلطة المحكم بالصلح في تطبيق قو اعد العدالة بعيدا عن اي قانون على اسـاس التنازل عن حق شخصي وهو الحق في الحصول على حمايـة القانون مـع التقبد بالنظام

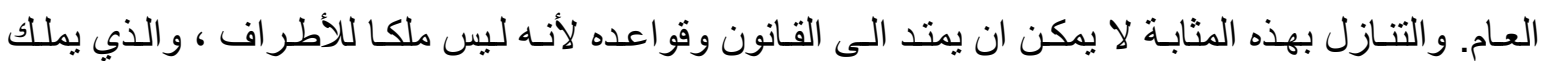
التنازل هو المحكم وحده ، فهو "المشرع" الذي باستطاعته النص على تخليه عن قانون معين او الغائهـ او احلال اخر محله ـ فالتنازل المقصود بهذا الوصف ليس تناز لا من احد الطرفين للطرف الاخر ، بـل هو تنازل مشترك من الطرفين لشخص ثالث هو المحكم(Yr).

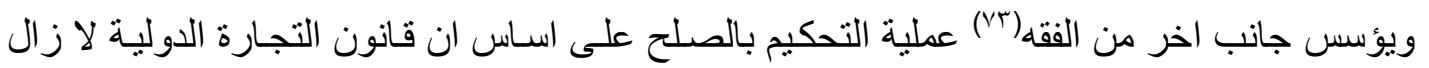
جديدا فيشوبه النقص في بعض جو انبه ، وهذا الامر يدفع المحكم لاستلهام الحلول للمسائل التي لم يتتاولها هذا القانون بـالتظظيم ، و لا يجد وسيلة لاستكمال هذا النقص كاستناده الى قو اعد العدالـة و الانصـاف. وأيـا كـان الاساس الذي يستند عليه التحكيم بالصلح ، فان الششروع يقر للحكم هذه السلطة مشروطة بتخويلها لـه من قبل الاطر اف لكن السؤال الذي يتبادر الى الذهن هو : كيف يتحدد مفهوم العدالة التي يؤسس المحكم حكمه هـ هـ

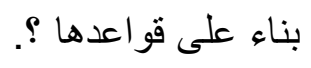

بداهة يتوجب على المحكم حينما يستوحي مبادئ العدالة ان يصدر قراره عن اعتبار ات موضو عية عامة لا من تفكير ذاتي خاص ، ومؤدى ذلك الا يتأثر في حكمه بأفكاره الذاتية .

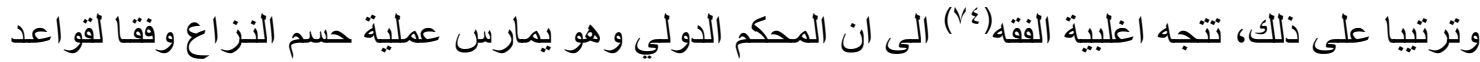
العدالة عليه ان يستمد هذه الاخيرة من مصـادر مختلفة و متتوعة تتباين بين عـادات واعر اف التجارة الدوليـة و المبادئ العامة المشتركة في القانون بوصفها تعبير ا عن العدالة التي يعرفها مجتمع التجارة والمـال ورجال الاعمال العابر للحدود التي تمثل قانون الاختصـاص (قانون القاضي) بالنسبة للمحكم المطروح عليه النزاع. وقد لاحظ البعض(vo(v) ان المحكم بالصلح نادر ا ما يؤسس حكمه بنـاء على اعتبار ات بحتـة تتعلق بالعدالة، لأنـه يفضل الرجوع الى قواعد اكثر دولية والتي يستخلصها بكل حرية من عادات واعراف التجارة الدولية. 
و أيا كان الحل الذي يتوصل اليها المحكم في منازعات التجارة الدولية ، حينمـا يكون مخولا بحسم

النزاع بمقتضى قو اعد العدالة والانصـاف ، فان حكمه لا يخضـع لرقابـة القضـاء في هذا الفرض ـ لان اتاحة الرقابة القضائية على ما توصل اليه المحكم من حكم حاسم للنز اع، يمثل وجها من وجوه الاستئناف ، الامر الذي لا يكون متاحا للقضاء في ظل مشروع قانون التحكيم التجاري العر اقي ـ فالقضـاء تقتصر سلطته على مر اقبة الحكم وتفحصه للتأكد من خلوه احدى اسباب البطلان ، وهو بمناسبة الطعن ببطلان حكم التحكيم او رفض تتفيذه ، لا يملك سوى مر اقبة مدى احترام المحكمين للمهمـة المخولين بها ، وهي حسم النزاع بالصلح دون التطرق لأساسـه ـ وتطبيقا لمـا تقدم ، قضـي بـان المحكمين احترمو ا سلطاتهم كمكمين بالصـلح ، ولم يتبين ذلك من خلال ذكر مهمتهم صراحة في الحكم فحسب ، بل ايضا بإظهار انهم راعو ا اعتبار ات الانصساف

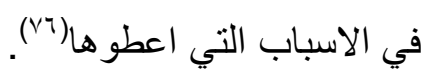

وقضي ايضا بأن المحكمة عند نظر ها في اسباب الطعن بطريقة الابطـال لقرار تحكيمي صـادر عن محكم مطلق لا تراقب سوى وجود هذه الاسباب دون صحتها ، ذلك ان امر صحتها ومناقتشته يدخل في بـاب

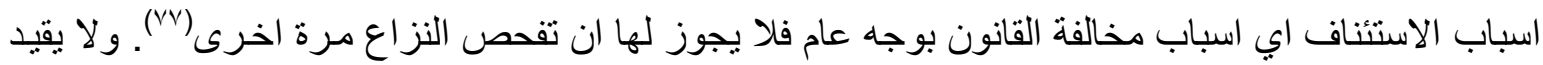
المحكم وهو يمارس التحكيم بالصلح وفقا لقو اعد العدالة والانصـاف سوى القيد الذي جاء في المـادة (• ب/ع) من المشروع الذي يتعلق بضـرورة مر اعاة شـروط العقد محل النزاع والاعر اف التجاريـة المتبعة في نوع

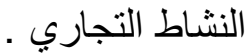

الإنمة

في سطور مـا تقدم تناولنـا بالدر اسـة موضـوع القانون الواجب التطبيق على النز اع المحكم فيـه ، وسجلنا في سبيل ذلك طائفة من النتائج ، وبعض التوصيات ، نبينها وحسب التقصيل الآتي :

أولاً : النتنائم:

ا ـ عكست صـياغة مشـروع قـانون التحكيم التجـاري العر اقي مدى اهتمـام الدولـة العر اقيـة بنظـام التحكيم ، كأسلوب لتسوية العلاقات الخاصة الدولية والداخلية ـ ويتبين ذلك بوضوح من خلال معرفة ان المشروع محل الدر اسة قد تبنى الكثير من المبادئ المعتمدة بعملية التحكيم ، في الانظمـة القانونية الوطنية و الدولية ، ومنها المبادئ التي تحكم تحديد القانون الواجب التطبيق على النزاع المحكم فيه . זـ اعطى المشروع الاختصاص في حسم النزاع المحكم فيه، للقانون الذي تتفق ار ادة اطر اف التحكيم على اختياره. فقانون الار ادة هو محل ارتكـاز عمل المحكم ، وعلى المحكم الا يتقاعس في البحث عن اختيـار الاطر اف الضمني في حالة غياب الاختيار الصريح . r- لا يعني اختيار الاطر اف لقانون معين هو قانون دولة بعينه ، بل من المتاح للأطر اف ان يختاروا اكثر من قانون دولة واحدة بشكل مجزئ لحسم النزاع ـ فضلا عن ذلك ، اتاح المشروع للأطر اف مكنة اختيار قو اعد تحسم النزاع ، و لا يشترط بهذه الاخيرة ان تكون ذات مصدر وطني ، بل يجوز اعتمـاد قو اعد التجارة الدوليـة المتعددة المصادر لحسم النزاع .

ع - في حالة غياب اتفاق الاطر اف الصريح او الضمني فعلى المحكم ان بضطلع بمهمة اختبار القانون الانسب للنزاع ، من خلال اعتماد الصلة و الرابطة الاقوى بين ذلك القانون وموضوع النزاع ـ و هو في سبيل تحديد 
ذللك القانون ، قيد المشروع سلطته بمر اعاة شروط العقد واعر اف التجارة السـائدة في نوع النشاط، و اعفاه من اعمال منهج تنازع القو انين بتحديد القانون الانسب مباشرة .

هـ للمحكم ممارسـة سـلطة حسـم النـزاع وفقـا لقو اعد العدالــة والانصـاف ، شـريطة اختيـار الاطـر اف لهـذا الاسلوب ـ ويترتب على ذللك اعفاء المحكم من مهمة تحديد القانون الواجب التطبيق على النزاع ، و لا رقابة لمحكمة البطلان على حكمه في هذا الاسلوب .

ثانياً : التوصيات

ا ـ تغيير تسمية المشروع من "قانون التحكيم التجاري" واستبدالها بتسمية "قانون التحكيم" او تسمية "قانون التحكيم في المسـائل المدنية و التجاريـة" ـ وذلك حتى يثـمل القانون باختصاصـه التحكيمـات التي تجري في نطاقي القانون المدني و القانون التجاري من جهة ، والنزاعات الداخلية و الدولية من جهة اخرى .

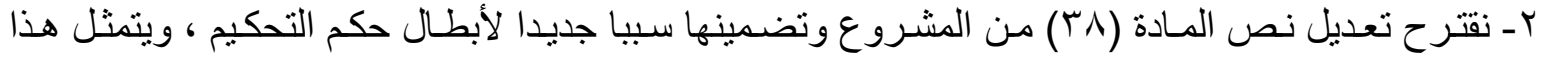
السبب باستبعاد المحكم للقانون الذي اختاره الاطر اف لحسم نز اعاتهم.

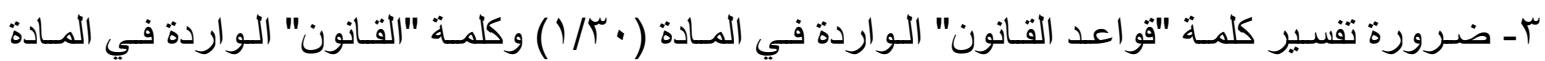

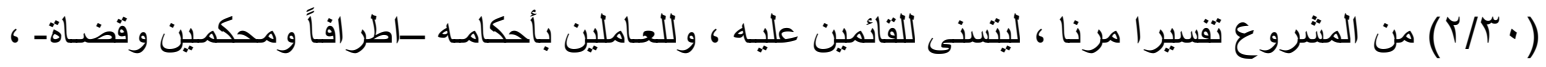
شمول قو اعد قانون التجارة الدولية بـالتطبيق ، و اعتباره احد القوانين المنافسـة لحكم النزاعـات التجاريـة ، من بين القو انين الصالحة للتطبيق عليها في العلاقات الخاصة الدولية .

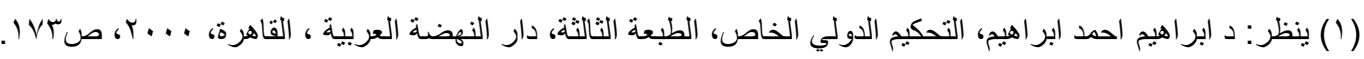

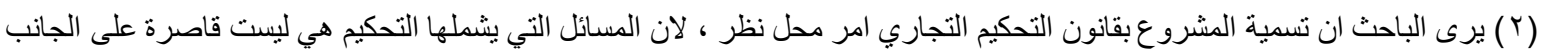

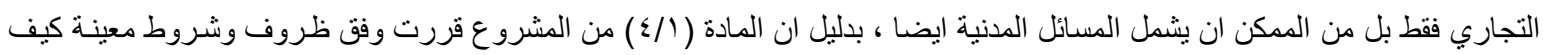
يكون التحكيم تجاريا دوليا ولم يخصص المشروع انطباقه على هذه النز اعات فقط مما يفهم منه قبول حسم المناز عات غير التجارية ايضا وفقا

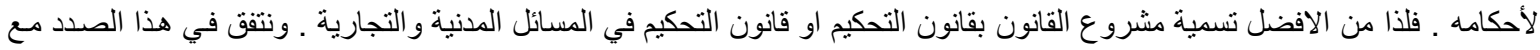

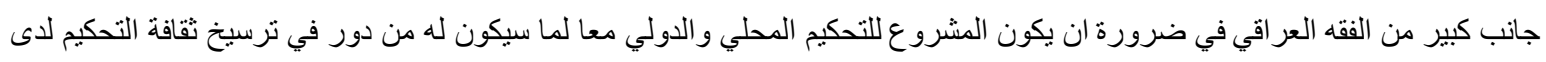

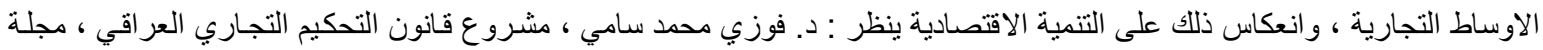

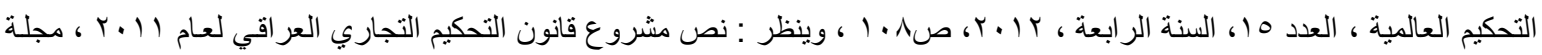

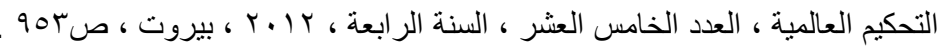

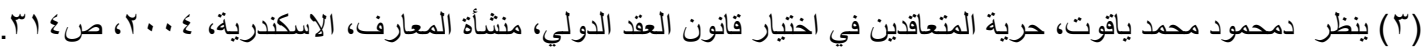
( ) ينظر: د.احمد عبد الكريم سلامة، نظرية العقد الدولي الطليق بين القانون الدولي الخاص وقانون التجارة الدولية ، دار النهضة العربية ،

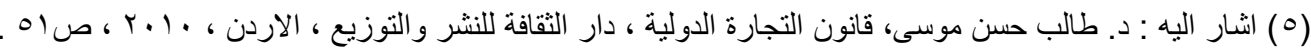

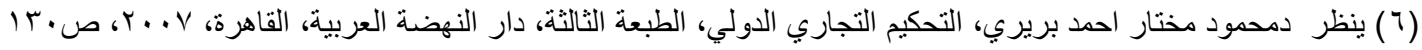

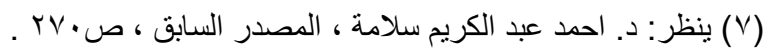

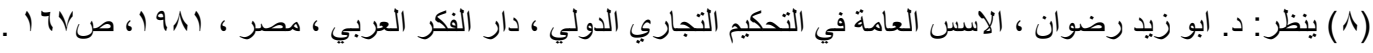

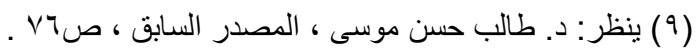

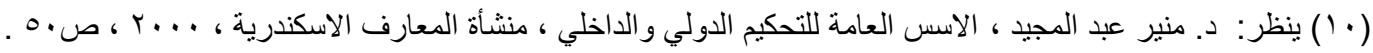

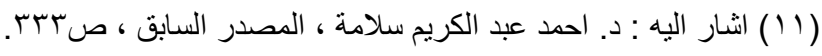

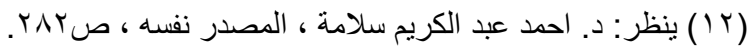




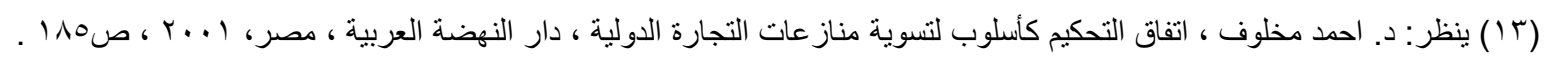

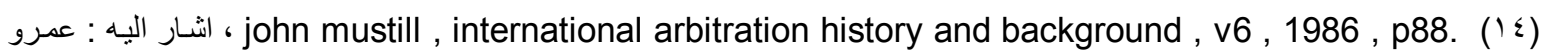
محمد ابر اهيم خليفة ، سلطة المحكم في اختيار القانون واجب التطبيق على موضوع النزاع ، اطروحة دكتور اه ، كلية الحقوق ، جامعة عين

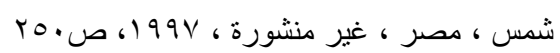
(10 ) ينظر : د. هثام علي صلادق ، القانون الواجب النطبيق على عقود التجارة الدولية ، الطبعة الثالثة ، دار الفكر الجامعي ، الاسكندرية ، I...

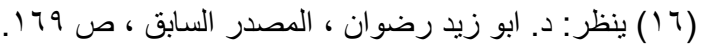

( V V ) ينظر : د. مصطفى الجمال و د. عكاشة عبد العال ، التحكيم في العلاقات الخاصة الدولية و الداخلية ، منشور ات الحلبي الحقوقية ، لبنان

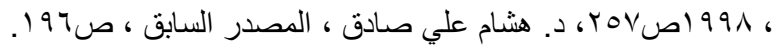

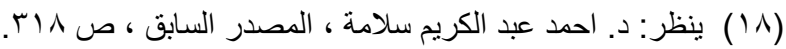

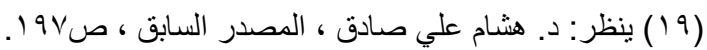

(Y.)

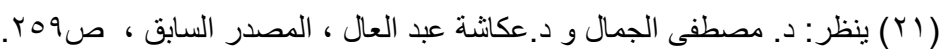

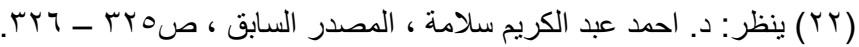
(YT)

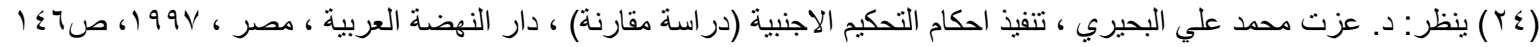

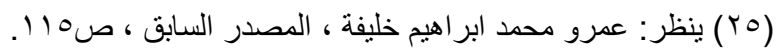

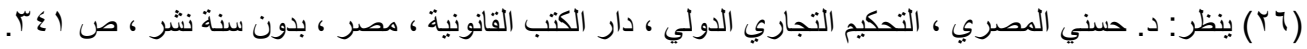

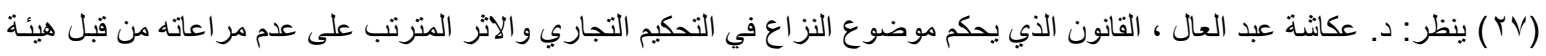

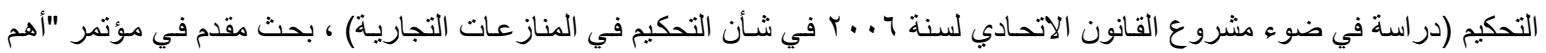

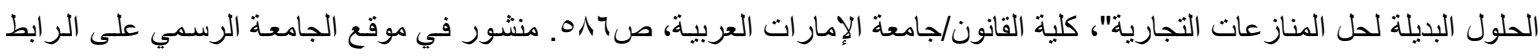
الالكتروني الآتي:

.http://slconf.uaeu.ac.ae/arabic-prev-conf2008.aspo

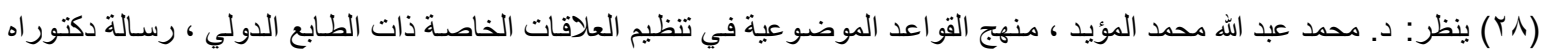

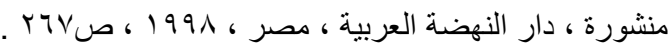

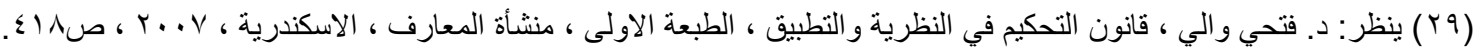

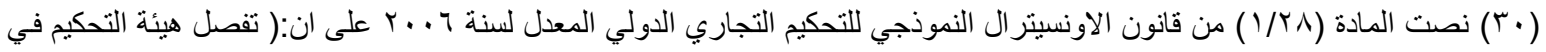

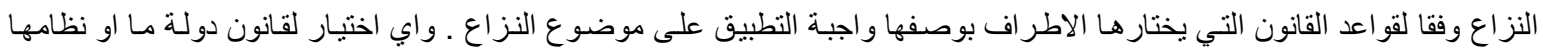

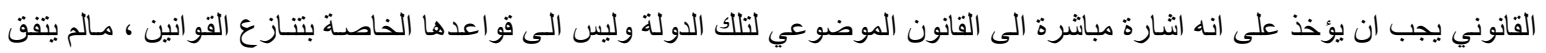

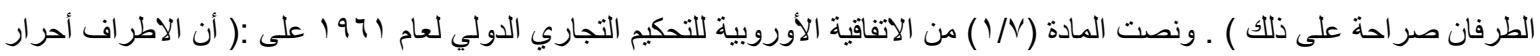

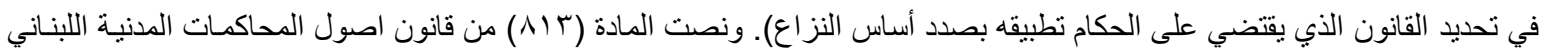
رقم •9 لسنة سمو 1 على :( يفصل المحكم في النزاع وفقاً للقو اعد القانونية التي اختارها الخصوم) ـ ونصت المـادة (1011) من المرسوم الفرنسي رقم (1؟) لسنة | ا ـ r حول تعديل النصوص المتعلقة بالتحكيم في قانون أصول المحاكمات المدنية على انه :( تفصل الهيئة التحكيمية

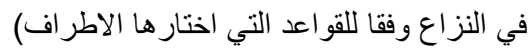

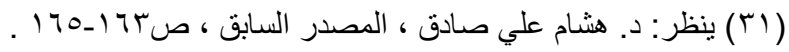

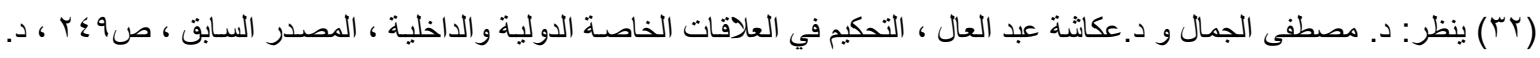

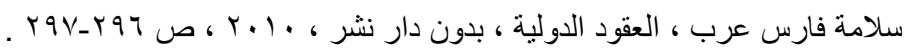
Margaret L. Moses , The Principles and Practice of Anternational Commercial

Arbitration, Cambridge University Press , New York , 2008 ,p70. ( ع ب) ينظر: د. عكاثنة عبد العال ، القانون الذي يحكم موضوع النزاع في التحكيم التجاري والاثر المترتب على عدم مر اعاته من قبل هيئة

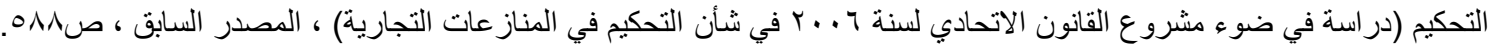

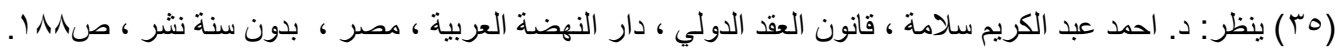


(דَr) ينظر: بقنيش عثمـان ، القانون الواجب التطبيق على المنازعات المعروضـة أمسام محكـة تحكيم المركز الدولي لتسوية مناز عـات

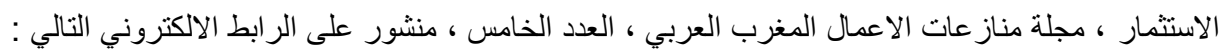

http://frssiwa.blogspot.com/2015/04/blog-post_2.html\#.VuSOUHOrLIV

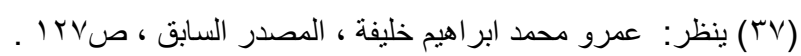

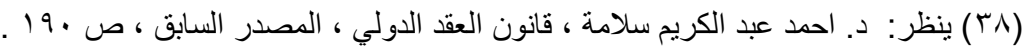

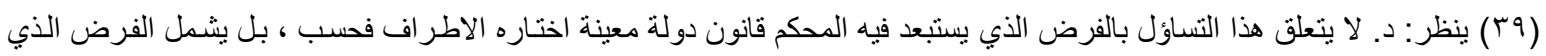
يتعلق باستبعاد القو اعد التي اتفق الاطر اف على تطبيقها ، ومنها قو اعد التجارة الدولية حسبما نرى .

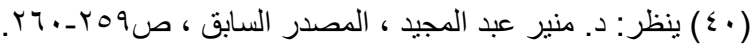
( إ) من ذللك مثلا ما نصت عليه المادة (به ) من قانون التحكيم المصري من ان :( لا تقبل دعوى بطلان حكم التحكيم الا في الاحوال الاتية : د- اذا استبعد حكم التحكيم تطبيق القانون الذي اتفق الاطر اف على تطبيقه على موضوع النزاع ).

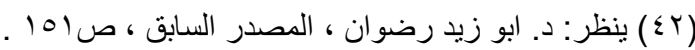
fouchard,gaillard,goldman on international commercial arbitration, Published by Kluwer Law International, London, 1999,p876. fouchard,gaillard,goldman, op.cit, p876.

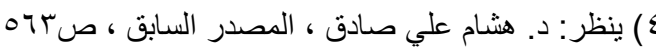

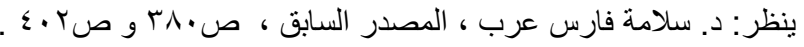

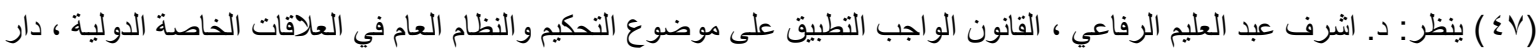

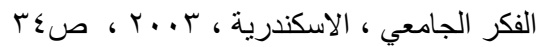

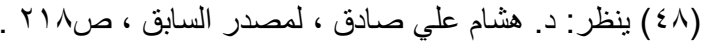

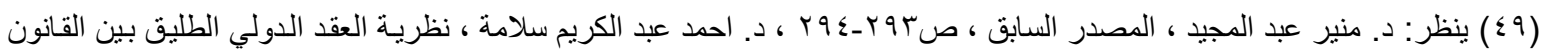

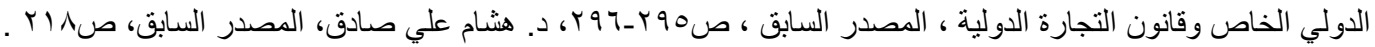

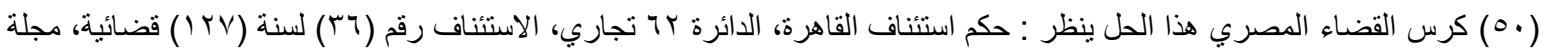

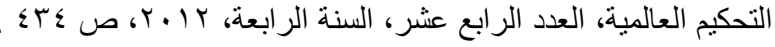

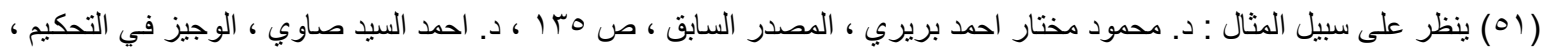

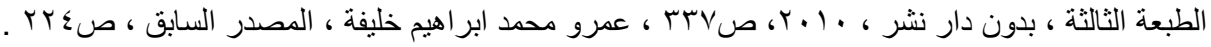

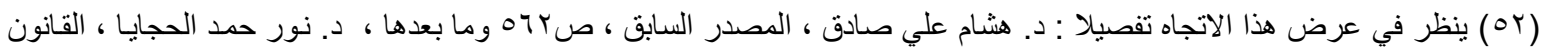
الذي يحكم النزاع المحكم فيه ، بحث مقدم في مؤتمر "أهم الحلول البديلة لحل المنازعات التجاريـة"، كلية القانون/جامعة الإمـار ات العربية، صنT TV . منشور في موقع الجامعة الرسمي على الر ابط الالكتروني الآتي: http://slconf.uaeu.ac.ae/arabic-prev-conf2008.aspo

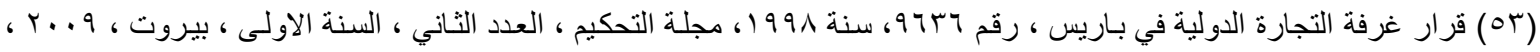
ص.

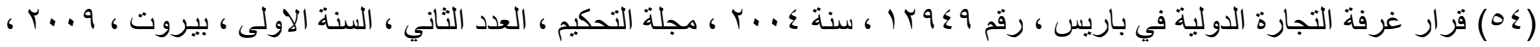
(ه ) ينظر : د. احمد عبد الكريم سلامة ، نظرية العقد الدولي الطليق بين القانون الدولي الخاص وقانون التجارة الدولية ، المصدر السـابق ،

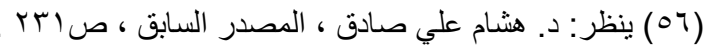

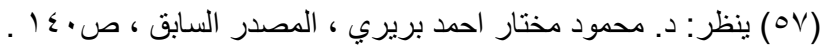

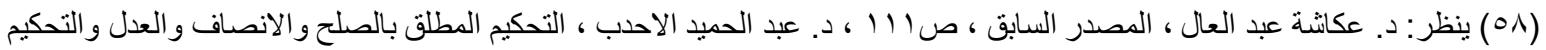

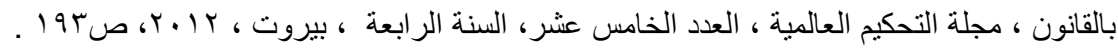

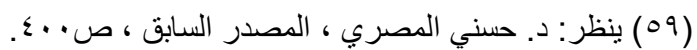

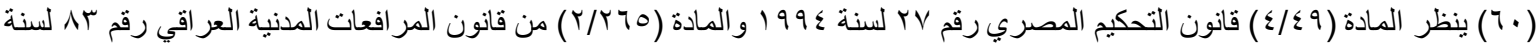




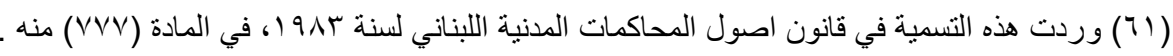

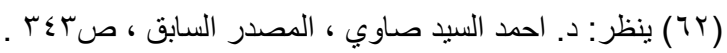

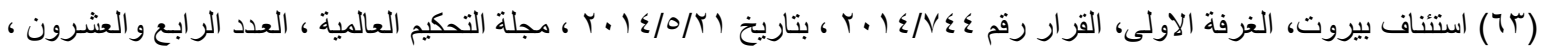

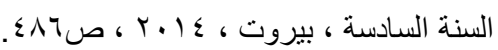

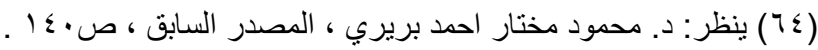

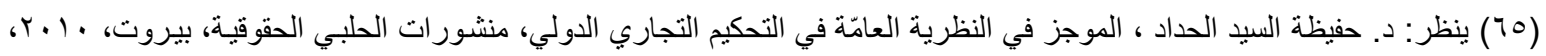

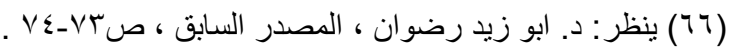

Margaret op.cit, p74.

L. Moses,

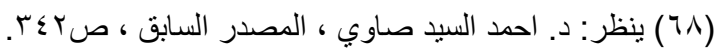

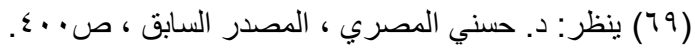

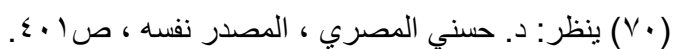

( إنظر : د. احمد عبد الكريم سلامة ، نظرية العقد الدولي الطليق بين القانون الدولي الخاص وقانون التجارة الدوليـة، المصدر السـابق ،

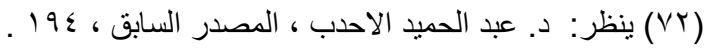$$
\text { ( }
$$

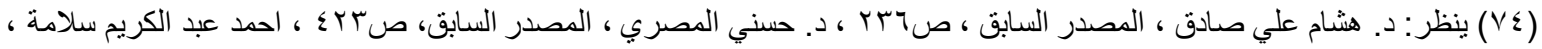

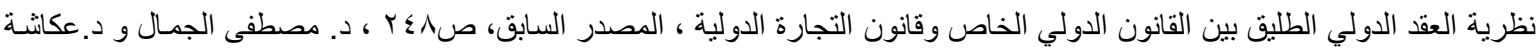

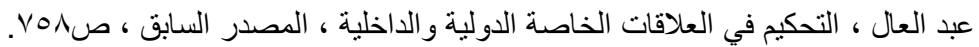

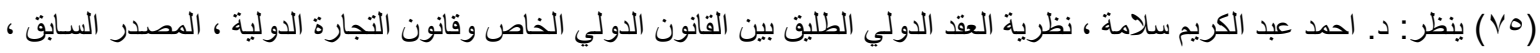

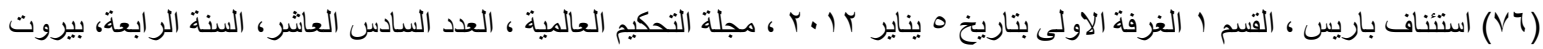

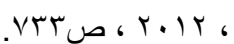

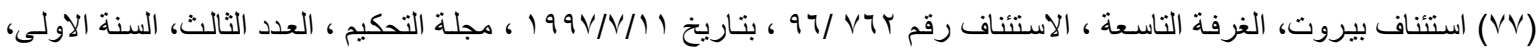
$.01 \cdot 0$. $1 . .9$

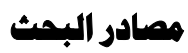

اولا : الكتب

د. ابر اهيم احمد ابر اهيم ، التحكيم الدولي الخاص ، الطبعة الثالثة ، دار النهضة العربية ، القاهرة ، .... أب.

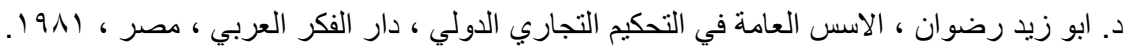

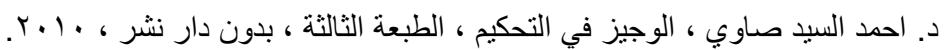

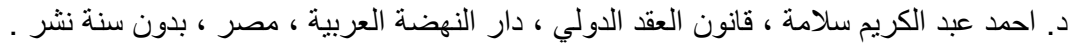
د. احمد عبد الكريم سلامة ، نظرية العقد الدولي الطليق بين القانون الدولي الخاص وقانون التون التجارة الدولية ، دار النهضة العربية ، القاهرة ، .1919

د. احمد مخلوف ، اتفاق التحكيم كأسلوب لتسوية مناز عات التجارة الدولية ، دار النهضة العربية ، مصر، ( ... ب.

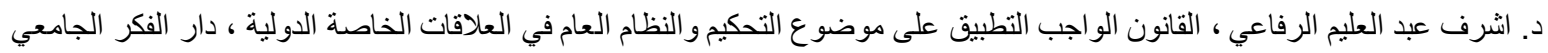

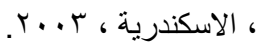

د. حسني المصري ، التحكيم التجاري الدولي ، دار الكتب القانونية ، مصر ، بدون سنة نشر.

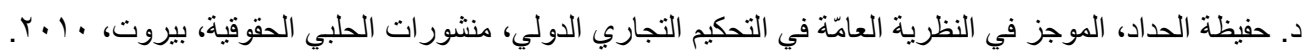

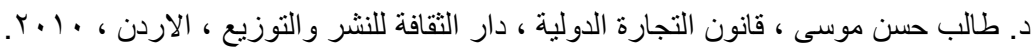

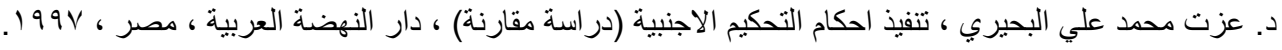

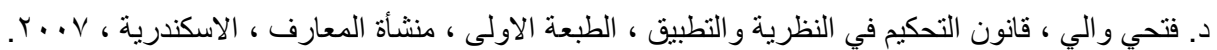


د. محمود محمد ياقوت، حرية المتعاقدين في اختيار قانون العقد الدولي ، منشأة المعارف ، الاسكندرية ، ؟ . . ب.

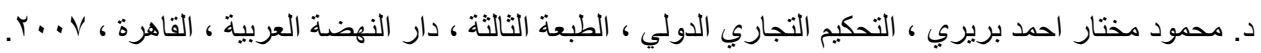

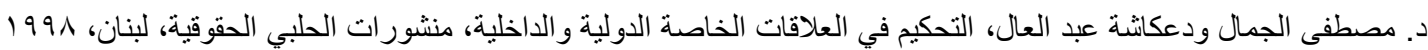

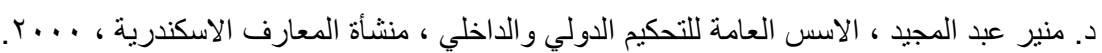

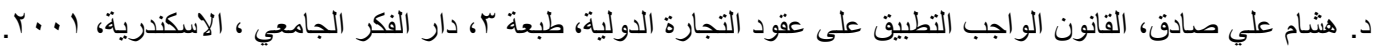

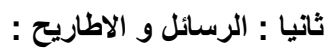
عمرو محمد ابر اهيم خليفة ، سلطة المحكم في اختيار القانون واجب التطبيق على موضوع النزاع ، اطروحة دكتور اه ، كلية الحقوق ، جامعة

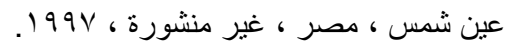
د. محمد عبد الله محمد المؤيد ، منهج القو اعد الموضوعية في تنظيم العلاقات الخاصـة ذات الطابع الدولي ، رسـالة دكتور اه منشورة ، دار النهضة العربية ، 1991. ثالثا: البحوث والاراسات: د. عبد الحميد الاحدب ، التحكيم المطلق بالصلح و الانصاف و العدل و التحكيم بالقانون ، مجلة التحكيم العالميـة ، العدد الخامس عشر، السنة

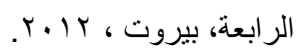

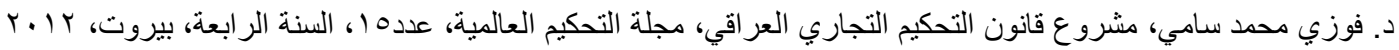

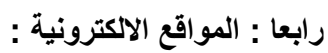
بقنيش عثمان ، القانون الواجب التطبيق على المنازعات المعروضة أمام محكمة تحكيم المركز الدولي لتسوية مناز عات الاستثمار ، مجلة

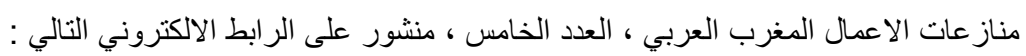
http://frssiwa.blogspot.com/2015/04/blog-post_2.html\#.VuSOUHOrLIV د. عكاثة عبد العال، القانون الذي يحكم موضوع النزاع في التحكيم التجاري والاثر المترتب على عدم مر اعاته من قبل هيئة التحكيم (دراسة

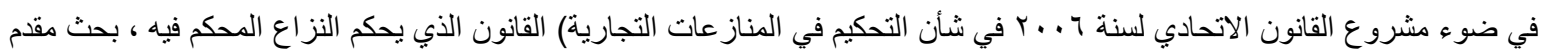
في مؤتمر "أهم الحلول البديلة لحل المنازعات التجارية"، كلية القانون/جامعة الإمار ات العربية. منشور في موقع الجامعة الرسمي على الر ابط الالكتروني الآتي: http://slconf.uaeu.ac.ae/arabic-prev-conf2008.aspo د. نور حمد الحجايـا، القانون الذي يحكم النزاع المحكم فيه، بحث مقدم في مؤتمر "أهم الحلول البديلة لحل المنازعات التجاريـة"، كلية

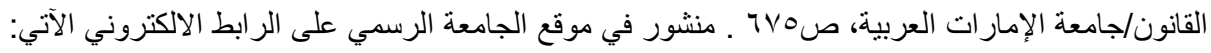
http://slconf.uaeu.ac.ae/arabic-prev-conf2008.aspo خامسا : القوانين والاتفاقيات الدولية: اولا : القوانين : قانون الاونسيتر ال النموذجي للتحكيم التجاري الدولي المعدل لسنة ج ج . ب.

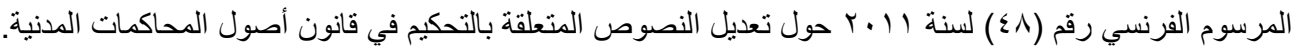

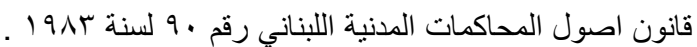
قانون التحكيم المصري رقم Vr لسنة ؟ 199

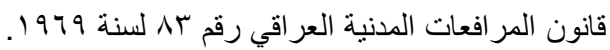
ثانيا : الاتفاقيات الدولية : الانية

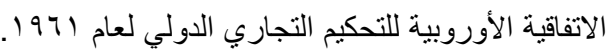
سادسا: المصادر الاجنبية : goldman on international commercial arbitration, Published by Kluwer Law gaillard, fouchard, . International, London, 1999 Margaret L. Moses, The Principles and Practice of International Commercial arbitration , Cambridge University Press, New York, 2008. 